\title{
Towards a New Research Programme on 'Banking and the Economy' - Implications of the Quantity Theory of Credit for the Prevention and Resolution of Banking and Debt Crises
}

\author{
Richard A. Werner ${ }^{*} 1$ \\ * Centre for Banking, Finance and Sustainable Development, \\ Southampton Management School, University of Southampton, Southampton SO17 1BJ \\ werner@soton.ac.uk
}

\begin{abstract}
The financial crisis has triggered a new consensus among economists that it is necessary to include a banking sector in macroeconomic models. It is also necessary for the finance and banking literature to consider how best to incorporate systemic, macroeconomic feedbacks into its modeling of financial intermediation. Thus a new research programme on the link between banking and the economy is needed. This special issue is devoted to this theme. In this paper an overview of the issues and problems in the economics and finance literature is presented, and a concrete, simple approach is identified of how to incorporate banks into a macroeconomic model that solves many of these issues. The model distinguishes between the type of credit that boosts GDP and credit that is associated with asset prices and banking crises. The model is consistent with the empirical record. Some applications are discussed, namely the prediction and prevention of banking crises, implications for fiscal policy, and a solution to the European sovereign debt crisis that stimulates growth while avoiding the corner solutions of euro exit or fiscal union.
\end{abstract}

Keywords: bank credit, banking and the economy, credit creation, disaggregation of credit, methodology, quantity equation, macroeconomics

JEL Classification: E41, E52, E58

\footnotetext{
1 Parts of this paper were presented at the European Conference on Banking and the Economy (ECOBATE 2011), held on 29 September 2011 in Winchester Guildhall. The paper was presented at the NCB Expert Meeting on Flow-of-Funds analysis at the European Central Bank on 28 November 2011 and at the Expert Meeting on 'The macroeconomic imbalances procedure (MIP): private sector balance sheet sustainability', European Commission, Directorate General Economic and Financial Affairs, LIME II, LAF, Centre Borschette, Brussels, 26-27 January 2012. The author would like to thank the organisers, Dr. Bernhard Winkler and Carlos Cuerpo-Caballero, for their kind invitations. None of the above are implicated by any potential errors. Should any addition to knowledge be found in this paper the author would like to acknowledge the source of all wisdom (Jeremiah, 33:3).
} 


\title{
1 Introduction
}

Since the outbreak of the financial crisis emanating from the US and UK in 2007 and 2008, macroeconomics has been the target of severe criticism. ${ }^{2}$ Thanks to the banking crisis, a broader spectrum of the public became aware of the fact that leading economic theories and models, as well as influential advanced textbooks in macroeconomics and monetary economics, did not feature money (e.g. Woodford, 2003), or banks (Walsh, 2003; Woodford, 2003). In the UK in 2010, the most commonly used textbook in macroeconomics on MSc Economics programmes was that of Romer (2006), Advanced Macroeconomics. ${ }^{3}$ On page 3, Romer explains that he is not covering money in his book, because:

"Incorporating money in models of growth would only obscure the analysis" (p. 3).

Without money there is also no financial sector. Likewise, the hitherto popular DSGE models had not included a financial sector, a deficiency not easily remedied due to their particular methodology and assumptions. Economists have increasingly conceded that this state of affairs is unsatisfactory. Alan Greenspan confessed in 2008 that he recognised a 'flaw' in mainstream models (Congress, 2010). Simon Johnson (2009) of the Peterson Institute of International Economics concluded:

\begin{abstract}
"Whether or not our economies manage to avoid a major global depression, economics is in crisis. ... [We need] to rethink a great deal about economics and how economies operate" (Johnson, 2009).
\end{abstract}

Donald Kohn (2009), as Vice-Chairman of the Federal Reserve, reflected the sense of embarrassment of the economics profession when having to admit to the public that our economic models simply assumed that banks did not exist:

\begin{abstract}
"It is fair to say ...that the core macroeconomic modelling framework used at the Federal Reserve and other central banks around the world has included, at best, only a limited role for ...credit provision, and financial intermediation. ...asset price movements and the feedback among those movements, credit supply, and economic activity were not well captured by the models used at most central banks."
\end{abstract}

These insights did not arrive a moment too early. Macroeconomics has experienced a number of major empirical challenges over the past thirty years or so, which have

2 For instance, Nassim Taleb said: "People who were driving a school bus blindfolded (and crashed it) should never be given a new bus. The economics establishment (universities, regulators, central bankers, government officials, various organisations staffed with economists) lost its legitimacy with the failure of the system. It is irresponsible and foolish to put our trust in the ability of such experts to get us out of this mess. Instead, find the smart people whose hands are clean.” (Taleb, 2009).

3 Survey of top 40 MSc programmes conducted by author in September 2010. 
largely remained unaddressed by the mainstream literature. The time may now be ripe for a more fundamental rethink in order to address them.

While economists seem to have taken the brunt of the public critique triggered by the crisis, researchers in the fields of banking and finance, often situated at business schools and supposedly more keenly interested in real world applications of their work, seem to have largely avoided criticism. However it could be argued that banking and finance research also failed in delivering prescriptions, tools and recommendations for appropriate regulation, supervision and risk management. While economists had dropped banking from their work, entire disciplines exist that focus almost exclusively on financial intermediaries. Why did they not warn about the looming banking crisis? Alan Greenspan said in 2008 that "modern portfolio management... the entire edifice... has collapsed" (Congress, 2010). Why did the apparently sophisticated approaches in risk management, portfolio optimisation and asset allocation seem of little help when the banking crisis struck?

A fundamental problem seems to be the very separation of disciplines into economics on the one hand, with the potential to capture systemic and macroeconomic aspects, and finance and banking on the other, with the potential to model banks in detail. The separation allowed the systemic importance of banks to remain unnoticed: The economists have tended not to model the financial infrastructure and banking, and the finance and banking researchers have tended not to be concerned with macroeconomic effects of the collective behaviour of financial intermediaries. Focusing on microeconomic studies of representative financial institutions, they neglected the systemic effects of collective bank behaviour that may affect the entire economy and thus generate important feedback to financial intermediaries. Both disciplines had developed in a way that blindsided them concerning banking crises.

It could thus be said that economics needs more finance and banking, while finance and banking need more economics. A new interdisciplinary research programme on 'Banking and the Economy' is required, based on the inductive, empirically-based research methodology. This special issue is devoted to a first conference on this theme, the European Conference on Banking and the Economy (ECOBATE), held on 29 September 2011 at Winchester Guildhall, and organised by the Centre for Banking, Finance and Sustainable Development, University of Southampton Management School. This paper is meant as a call for such a new interdisciplinary research programme on banking and the economy. To illustrate the need and importance of this topic, I survey the state of modern macroeconomics, combined with commentary on relevant finance theory, and point out the many empirical challenges that need to be overcome. But to take the discussion a step further, I present an introduction to a concrete model linking banking and the economy via the reflection of a fundamental, yet usually neglected fact about banks of which both finance and economics experts are often unaware for the majority of their career: banks create the money supply through the process of 'credit creation'. This topic is also the focus of the keynote address of the ECOBATE conference, by Lord Adair Turner (2011), FSA Chairman. This special issue carries selected contributions to the conference. As there is also a need for a forum to discuss policy-focused papers, a selection of such contributions, including Lord Turner's, can be found in a special policy section. 
In this paper I first discuss seven major empirical puzzles in macroeconomics and then a simple modification of the most basic macro model, the quantity equation. The latter enables the introduction of the banking sector into macroeconomic models and offers solutions to the puzzles. I next discuss the justification for this model and its empirical record. This is followed by an application of the model to current questions of how to prevent banking crises, how fiscal policy can be effective or ineffective depending on the role and contribution of the banking sector, and how to solve the European sovereign debt crisis.

\section{Major 'Anomalies’ in Macroeconomics}

\subsection{The Velocity Decline and the Inability to Define Money}

The widespread criticism of recent macroeconomic approaches suggests that the research agenda culminating in models that neither feature banks nor incorporate monetary variables has not been successful. If macroeconomics has proceeded down the wrong path, one needs to return to the crossroads at which the path to moneyless real business cycle models, DSGE formulations or versions of Woodford's (2003) approach was taken.

It may not be possible to identify a single point in time, but the late 1980s cannot be far off: Until about the mid-1980s, the hitherto prevailing approaches (classical, many neo-classical, Keynesian, monetarist and post-Keynesian approaches, as well as most eclectic models), despite their differences, had much in common. They still included a monetary aggregate that was linked to nominal GDP through the quantity equation:

$$
\mathrm{MV}=\mathrm{P} \mathrm{Y}
$$

whereby $\mathrm{M}$ stands for the money supply (measured and defined variously as M0, M1, M2, M3 or M4), V denotes the (income) velocity of money (originally the number of times gold was said to circulate during an observation period), $P$ the GDP deflator (the appropriate price level) and Y symbolises real GDP. PY hence represents nominal GDP. Expressed in logarithms, this relationship can also be stated as:

$$
m+v=p+y
$$

Friedman had famously claimed that this equation was characterized by a 
"uniformity... of the same order as many of the uniformities that form the basis of the physical sciences. And the uniformity is in more than direction. There is an extraordinary empirical stability and regularity to such magnitudes as income velocity that cannot but impress anyone who works extensively with monetary data" (Friedman, 1956, p. 21).

He still called it "an identity, a truism" decades later (Friedman, 1992, p. 39). Handa (2000) still wrote, somewhat confidently, that equation (1)

"is valid under any set of circumstances whatever since it can be reduced to the statement: in a given period by a given group of people, expenditures equal expenditures, with only a difference in the computational method between them" (p. 25).

Until about the mid-1980s equations (1) or (2) were the widely accepted workhorse that represented the link between the tangible ('real') economy and the financial/monetary sectors. However, from the early 1980s onwards, faith in this link had been increasingly shaken by the widespread and growing empirical observation that velocity had become erratic, was declining significantly and the money demand function was unstable (e.g. Hendry, 1985; Belongia and Chalfant, 1990; Boughton, 1991). The 'quantity equation' relationship, expressed as a stable income velocity, "came apart at the seams during the course of the 1980s" (Goodhart, 1989). This phenomenon is known as the 'velocity decline', 'breakdown of the money demand function', or even the 'mystery of the missing money' (Goldfeld et al., 1976). It has been described as a world-wide "puzzling" anomaly (Belongia and Chalfant, 1990). Once "viewed as a pillar of macroeconomic models", the quantity equation "is now ... one of the weakest stones in the foundation" (Boughton, 1991). As a result, economists could not identify a reliable relationship between a monetary aggregate and nominal GDP.

The implications of the observed velocity decline and breakdown in the money demand function for macroeconomics were devastating. This empirical failure not only discredited monetarism, but posed a major obstacle to all the other schools of thought as well, most of which had previously relied on the quantity equation in one way or another.

Attempts at explaining this phenomenon raised more questions than they answered: usually attributed to financial deregulation and innovations (e.g. Judd and Scadding, 1981; Gordon, 1984; Hetzel, 1984; Roley, 1985; Miller, 1986), it was argued that this lowered velocity (as money was used more efficiently). But the empirical record of financial deregulation was to increase the volume of transactions, suggesting a higher speed of transactions. After an initial burst of papers attempting to explain this puzzle, the discipline turned away from it - not because the problem had been solved: the apparent anomaly grew bigger over time, and no convincing explanations had been provided.

As one monetary aggregate after another succumbed to an unstable relationship with nominal GDP, the profession became ever less specific about the very definition 
of money. Today, textbooks, as well as leading central bank publications, state that they do not know just what money is. In the words of then Federal Reserve staff:

"...there is still no definitive answer in terms of all its final uses to the question: What is money?" (Belongia and Chalfant, 1990, p. 32).

Miller and Van Hoose (1993) concluded their chapter on money:

"Although there is widespread agreement among economists that money is important, they have never agreed on how to define and how to measure money" (p. 42).

The empirical failure to define money without much ambiguity has been one of the weaknesses of the macroeconomics prevalent until about the mid-1980s, and it is one that remains unresolved within the mainstream.

Motivated by the velocity decline and the inability to define money clearly, in the 1980s leading economists called for the adoption of "an alternative paradigm" (Spindt, 1987; Judd and Scadding, 1982; Gordon, 1984; Roley, 1985). We know that this was the time at which the paradigm of moneyless economic models, real business cycle theories and supply-side economics became influential. Given that the profession had a fundamental problem with handling money, such moneyless models must have become more appealing to economists. If nothing else, they seemed to offer an escape route from an apparently intractable problem. However, adopting nonmonetary models because previous attempts at modeling money had not been successful is not an acceptable scientific research methodology. The currently prevailing paradigm therefore must face the criticism that it was potentially adopted as a form of escapism. Instead of rising to the challenges posed by the velocity decline and getting to the root of the problem, economists simply assumed away the problem, by operating on the empirically unsupported premise that money (and banks) did not matter.

This development also began to drive a wedge between the research agendas of monetary and macroeconomists on the one hand, and banking and finance researchers on the other. It turned out to be a costly separation, as especially the systemic (macroeconomic) implications of collective bank actions seemed to fall between two stools.

However, there were other challenges which indicated already many years ago that not all was well. If adopting non-monetary models was meant to sidestep the empirical failure of prior approaches, economists must have felt haunted when other empirical challenges arose that have proven equally devastating for the non-monetary models. 


\subsection{Banks and Banking Crises}

The role of banks has remained a persistent puzzle in conventional macroeconomics - whether of the pre- or post-1980s type. Because of the belief that they are mere financial intermediaries without any special features that would justify a unique representation, they have not been explicitly modelled in a meaningful way in major macroeconomic theories and models over the past thirty years. There is however a small though important body of evidence to the effect that banks are special in some way that standard theory cannot explain (e.g. Fama, 1985; Peek and Rosengren, 2000; Ashcraft, 2005; Werner, 1992; Werner, 2005; Leary, 2009; Voutsinas and Werner, 2011). Blanchard and Fischer (1989) pointed out already more than twenty years ago:

"The notion that there is something about banks that makes them 'special' is a recurrent theme." (p. 478).

But since conventional approaches failed to identify the nature of this special feature, economists did not feel compelled to include banks in their modelling efforts. With banks unexplained, so has been the powerful phenomenon of the recurring banking crises, which time and again provide a stark reminder that banks indeed have an important role to play in the economy. Caprio and Klingebiehl (1999) have shown that there have been well over a hundred banking crises in the past fifty years and their number and magnitude seems to have increased during that time, not decreased. See also the more recent work by Reinhart and Rogoff (2008). The 'anomaly' of banking crises became the Achilles heel of the moneyless theories that had become dominant since the mid-1980s.

\subsection{The Empirical Puzzle of Interest Rates}

There are other significant 'anomalies' that have challenged the old as well as the new mainstream approaches. While theories place great store by the role of interest rates as the pivotal variable that has significant causal force, empirically they seem far less powerful in explaining business cycles or developments in the economy than theory would have it. ${ }^{4}$ In empirical work, interest rate variables often lack explanatory power, significance or the 'right' sign..$^{5}$ When a correlation between interest rates and economic growth is found, it is not more likely to be negative than positive. ${ }^{6}$ Interest rates have also not been able to explain major asset price

4 See Melvin (1983) and Leeper and Gordon (1983), who found little support for the so-called liquidity effect of interest rates on the money supply.

5 King and Levine (1993) did not find evidence to support the hypothesized relationship between real interest rate and economic growth in a cross-section of countries. Taylor (1999) found that the link between real interest rates and macroeconomic aggregates such as consumption and investment is tenuous.

${ }^{6}$ Kuttner and Mosser (2002) pointed out the positive correlation between GDP growth and interest rates in the US between 1950 and 2000. Dotsey, Lantz and Scholl (2003) examined the 
movements (on Japanese land prices, see Asako, 1991; on Japanese stock prices, see French and Poterba, 1991; on the US real estate market see Dokko et al., 1990), nor capital flows (Ueda, 1990; Werner, 1994) - phenomena that in theory should be explicable largely through the price of money (interest rates). Furthermore, in terms of timing, interest rates appear as likely to follow economic activity as to lead it.?

This became apparent when the Japanese central bank lowered interest rates over a dozen times in the 1990s, while the economy continued to stagnate and the money supply failed to expand. But Keynesian, post-Keynesian and even most monetarist advice was based on a monetary transmission mechanism via interest rates.

Again, there were many attempts at explaining this phenomenon, producing the voluminous 'credit view' literature (including the 'bank lending view' and the 'balance sheet channel' approach; see Bernanke and Gertler, 1995). These attempts also failed: They could not resolve the empirical puzzle, because according to its proponents the additional credit channel of monetary transmission should enhance the role of interest rates. This was evidently not the case in Japan or a number of other major economies. As a result, key proponents began to distance themselves from this approach (Bernanke, 1993; Bernanke and Gertler, 1995).

An attempt was made to explain the apparent failure of falling interest rates to stimulate the economy by reviving the 'liquidity trap' argument, originating in Keynesian approaches, and subsequently adopted by rational expectations theories (Krugman, 1998). While there is a widespread perception that the 'liquidity trap' explanation has been successful, in fact it failed to even ask the right question, let alone offer an answer to it: The liquidity trap argument is about a situation where interest rates have fallen to their lowest point, and it merely argues that, at this point, interest rate-based monetary policy cannot be effective (since rates cannot be reduced further). However, in Japan interest rates reached their lowest point only in March 2003, after over a decade of recession and over a dozen interest rate reductions. As to the relevant question at hand, namely why repeated interest rate reductions over a decade have failed to stimulate the economy, the liquidity trap argument has nothing to say. ${ }^{8}$ As it turns out, the liquidity trap argument is merely the restatement of the tautology that rates cannot fall further when they have fallen to the lowest possible point.

behaviour of real interest rates. Their results disclosed the real interest rate series is contemporaneously positively correlated with lagged cyclical output. Other studies finding a positive correlation between interest rates and growth include Gelb (1989), Polak (1989), Easterly (1990) and Roubini and Sala-i-Martin (1992). This positive relationship between interest rates and growth is also acknowledged in a leading textbook in advanced macroeconomics (Sorensen and Whitta-Jacobsen, 2010). For a comparative empirical study on the US, UK, Germany and Japan, see Werner and Zhu (2011).

7 While Stock and Watson (1999) find that the nominal rate is a leading business-cycle indicator, short-term interest rates, since influenced by central banks, tend to follow nominal GDP growth. The same also seems to apply to long-term interest rates (Werner, 2005). Gurkaynak, Sack, and Swanson (2005) showed that long term interest rates react to various macroeconomic shocks that in the conventional macroeconomic models are only expected to affect short-term interest rates.

${ }^{8}$ For a survey of how the literature has dealt with the ineffectiveness of interest rate policy in Japan, see Werner (2006). 
For interest rates to play the role theory suggests, the money and credit markets have to be in equilibrium. But Japan's recession, about to enter its third decade, makes sport even of the contention that in the medium to long run markets are in equilibrium. Many economists have been trained to avoid contemplating the possibility that markets may never be in equilibrium. Yet, this is a distinct possibility. In such a world, it would not be prices (such as interest rates) that determine outcomes, but quantities (such as the quantity of credit). Further, rationing implies that an allocation decision is made that can be decided on the basis of non-price or even non-market factors, such as the extraction of 'rents' or benefits (Werner, 2005). Even Blanchard and Fischer (1989) noted, in a comment that echoes their sentiment on the missing role of banks:

"A recurrent theme in the literature and among market participants is that the interest alone does not adequately reflect the links between financial markets and the rest of the economy. Rather, it is argued, the availability of credit and the quality of balance sheets are important determinants of the rate of investment" (p. 478).

This has stirred interest in the credit rationing argument (Jaffee and Russell, 1976; Stiglitz and Weiss, 1981). However, even this eminently sensible explanation raised more questions than it answered: the credit rationing argument itself does not explain why available alternatives to domestic bank credit (foreign bank credit, direct finance, equity issuance) failed to compensate for credit supply constraints. In effect, credit rationing is a microeconomic argument without any explicit macroeconomic implications. However, it is macroeconomic issues that require explanation: why have interest rate reductions failed to stimulate the economy, and why could non-bank sources of funding not compensate for lack of bank credit?

\subsection{The Failure of Supply-Side Explanations}

Some economists consider ineffective demand management policies - such as in Japan's case - as evidence that supply-side economic reforms should be adopted instead. However, the supply-side advice to increase productivity and factor input mobilization through deregulation, liberalization and privatization, derived from new classical theories, has hardly fared any better than the conventional demand side economics: there is no evidence that the significant textbook supply-side structural reforms that Japan undertook in the past 30 years has helped in the short-term or the long-term, or that structural factors were actually the cause of the recession (see Werner, 2004). This adds to the older empirical challenge that the phenomenal economic performance of Japan, Taiwan, Korea and Germany (mid-1930s to early 1970s) and China (since 1982) has posed to mainstream approaches. The latter argued that only economies with freer markets should be efficient and productive, while economies using non-market mechanisms and government intervention should be less so. As Chalmers Johnson (1999) argued: 
'Japan's 'flagrantly flouting all received principles of capitalist rationality', to use Dore's words (1986, p. 18), was turning it into one of the world's richest big nations and the model for all the other countries of East Asia, including China” (p. 33).

Proponents were reduced to arguing, somewhat improbably, that Japan, Taiwan, Korea, and China, as well as Germany earlier on, were successful despite their nonmarket mechanisms and government intervention in the form of incentive-compatible institutional design and allocation of credit, not because of it. The implication of this argument is that these countries would have been even more successful, had they not engaged in such policies (see Johnson, 1988, for an eloquent rebuttal).

Thomas Kuhn (1962) argued in his account of the growth of scientific knowledge that researchers operate within generally accepted 'paradigms'. The process of shifting to a new, more advanced paradigm is not necessarily smooth, as the old paradigm is supported by those who have made a career out of its propagation. Lakatos (1970) argued that defenders of the 'old paradigm' (defined by him as a research programme) would adopt 'immunisation' strategies, such as the introduction of ad hoc assumptions, to try to 'protect' their 'core' beliefs against contrary empirical evidence - a practice already condemned by Karl Popper (1968) as unscientific. As the number of inexplicable facts rises ('anomalies', in Kuhn's terminology), the call for a new paradigm should become louder. The new paradigm must be able to explain at least as much as the previous approach and in addition also account for the many 'anomalies' of the old paradigm, thereby encompassing it.

If the analysis of Kuhn and Lakatos applies to macroeconomics, then defenders of the conventional approaches should have become increasingly embattled over the past thirty years, and ever more reliant on inconsistent $a d$ hoc assumptions, while criticism of their approaches spread.

Proponents of real business cycle theories have indeed argued that macroeconomics should respond to the challenges posed by the financial crisis by incorporating a financial or banking sector into DSGE models. This is recognizable as an ad hoc modification of an incompatible approach. Instead, a new paradigm is needed. Already before the crisis a number of influential economists, including Joseph Stiglitz and collaborators had renewed the call for a "new paradigm". The slow but steady rise of non-mainstream theories over the past twenty years, including institutional economics, experimental economics, psychological economics, behavioural economics and economic history - all sub-disciplines with an empirical orientation - suggests that momentum is building in favour of a shift towards a model developed from an inductive research methodology.

I believe that a convincing new paradigm can only arise from an inductive approach, avoiding the errors of the prevailing paradigm, which was built on the hypothetico-deductive method that starts with so-called first principles by adding unrealistic assumptions to erroneous axioms. A new paradigm must rise to the challenge of explaining at least the seven central empirical puzzles in macro- and monetary economics:

9 See Stiglitz (2001), Stiglitz and Greenwald (2003). 
(1) The apparent velocity decline; (2) the identification problem of money, and (3) of what makes banks special (while incorporating this feature appropriately into a macroeconomic model); (4) why there are recurring banking crises; (5) the ineffectiveness of over a decade of interest rate reductions in stimulating growth in Japan (and a growing number of other countries), and, more generally, the link between interest rates and growth; (6) the success of the German and East Asian economic model, despite wide-spread government intervention and use of non-market mechanisms; and (7) the ineffectiveness of supply-side reforms (deregulation, liberalization, privatization) in enhancing economic performance in Japan and other countries.

In the following section it will be argued that - following the inductive method empirical observation of key aspects of banking activity can be used to construct such an alternative approach by modifying the last common macro model that included money: the quantity equation. In response to the empirical failures of equations (1) or (2) economists in the late 1980 s could have persisted in identifying the reasons for its failure and formulated an alternative framework, instead of abandoning it. In fact I first proposed such a modification in its basic form in 1991 (Werner, 1992), but economists had already embarked on their moneyless research paradigm, while finance researchers showed little interest in systemic issues. The model has however stood the test of time well. I would argue that the past twenty years have further strengthened its appeal.

\section{Two Flaws in the Quantity Equation and How to Address Them}

\subsection{The Role of Financial Transactions}

There are two flaws in the use of the most widely accepted version of the quantity equation (equations 1 or 2). As a result, it is neither "valid under any set of circumstances whatever" (as Handa, 2000, still claimed), nor "an identiy, a truism" (Friedman, 1990). To the contrary, it is a special case that applies only under exceptional circumstances. More often than not it is incorrect, resulting in the apparent 'velocity decline'.

The first flaw emerges when reconsidering the original formulation by Irving Fisher (1911), based on Newcomb (1885) and John Stuart Mill (1848), which can be stated as follows:

$$
\mathrm{M} \mathrm{V}=\mathrm{P} \mathrm{Q}
$$

Fisher said that the 'effective' money MV (assumed to circulate and be used for transactions) is equal to the value of transactions (the sum of all pairs of prices times 
quantities transacted). ${ }^{10}$ We can rephrase this slightly and say that, in its original form, the quantity equation stated:

The total value of transactions during any time period must be the same as the amount of money used to pay for these transactions.

This is now an equation that indeed is "valid under any set of circumstances whatever" and is of course the reason why the quantity equation is also known as the 'equation of exchange'. ${ }^{11}$ But there was an important drawback to Fisher's equation. When attempting to apply it in practice by using data, $\mathrm{M}$ and $\mathrm{P}$ could be readily identified. $\mathrm{V}$ is hard to measure and thus had to be the residual. Thus data on transactions Q were necessary. But they did not exist, at least not in official publications (today central banks could easily publish such figures - available to them in real time due to their function as clearing house of all bank transactions, which in turn account for a likely $97 \%$ of all transaction values in the economy - but they have chosen not to do so). As national income accounts were becoming increasingly available, Pigou (1917) and several of his colleagues at Cambridge University argued that the stock of money should be proportional to 'total nominal expenditures', which could be represented by the expenditure-side of GNP. Many Cambridge economists therefore replaced PQ with PY, yielding the most widely-known formulation of the quantity equation in (1) above. ${ }^{12}$

This change in the definition of the quantity equation is usually undertaken with minimal justification. Milton Friedman, for instance, explains that

"Fisher, in his original version, used $T$ to refer to all transactions - purchases of final goods and services..., intermediate transactions..., and capital transactions (the purchase of a house or a share of stock). In current usage, the item has come to be interpreted as referring to purchases of final goods and services only, and the notation has been changed accordingly, $T$ being replaced by $y$, as corresponding to real income" (Friedman, 1990, p. $38)$.

While it is undoubtedly true that it "has come to be interpreted as referring to purchases of final goods and services only", which can be represented by GDP, Friedman fails to tell us why this is justified and what the implicit assumptions are. From a comparison with Fisher's earlier formulation we know that equation (1) is a special case that is only accurate if:

10 Fisher originally used the notation MV=PT, whereby $\mathrm{T}$ stands for the quantity of transactions.

11 Since Fisher had the concept of species in mind as money M, and since he realized that the total volume of transactions was much larger than the stock of gold or precious metals, he, like other economists at the time, felt that banking or other financial innovations served to economise on this stock of gold. Thus some kind of 'multiplier' was necessary - the number of times one unit of gold money M was used for transactions during the period of observation. This is velocity $\mathrm{V}$.

12 Only marginally different by solving for $\mathrm{M}$, thus representing it as a money demand function, with $1 / \mathrm{V}$ on the r.h.s. renamed ' $k$ ' - the 'Marshallian k', named in honour of another Cambridge economist. 
or, in other words, if nominal GDP is a robust proxy for the value of total transactions in the economy for which money is changing hands. When considering growth rates, the lesser requirement applies that transactions proxied by GDP are a constant proportion of total transactions. However, it is neither clear that GDP accurately reflects all transactions in the economy nor that GDP-based transactions are a constant proportion of total transactions. Friedman (1990, p. 38), casually inserts the formulation "if we restrict purchases to final goods and services..." in his explanation of equation (1). But as Friedman acknowledges, Fisher originally included asset transactions. These constitute an important potential use of money M. They may be of substantial volume in modern economies - often a multiple of GDP yet are not included in the GDP statistics, as the latter reflect income, value added in production and services or expenditure on goods and services only. Capital gains on assets are not included in the income definition. Financial sector transactions affect wealth, but are not part of income and hence GDP (for more details on national income accounting, see UN 1993, 2003, or Lequiller, 2004). Likewise, the majority of real estate transactions are not part of the GDP statistics.

John Stuart Mill (1848) suggested that one must consider the possibility that money is used not for goods (and services), but instead for financial transactions, such as the purchase of securities. ${ }^{13}$ Jeremy Bentham did so as well, and in fact came to different, probably more accurate, conclusions than Mill - but the publication of his key contribution to this topic was delayed by well over a century and remains little known (see Bentham, 1952-54). ${ }^{14}$ Fisher, and after him Keynes, suggested to distinguish between transactions arising from the sale or purchase of finished goods and services (which can be measured by GDP) and financial transactions that are not related to national income. ${ }^{15}$ Theoretical and empirical work using a similar distinction includes Selden (1956), Spindt (1985), Cramer (1986), Stone and Thornton (1987), Niggle (1988) and Allen (1989). The UK's Central Statistical Office (1986) argued that the total value of transactions should be used in the quantity equation, while GDP was merely a subset of transactions involving final output. ${ }^{16}$ It can therefore be said that the need to distinguish between GDP-based transactions and non-GDP-based transactions has been pointed out clearly in the literature, although this was not successfully linked to a corresponding separation of relevant monetary aggregates. $^{17}$ Yet, the mainstream use of the quantity equation has remained confined

13 It frequently happens that money, to a considerable amount, is brought into the country, is there actually invested as capital, and again flows out, without having ever once acted upon the markets of commodities, but only upon the market of securities, or, as it is commonly though improperly called, the money market" (Book III, chapter 8, para. 18).

14 Thanks to Gunnar Tomason for pointing this out.

15 Fisher (1926) distinguished between income and financial transactions, Keynes (1930) between 'industrial' and 'financial' transactions.

16 As quoted by Howells and Biefang-Frisancho Mariscal (1992).

17 See also Werner $(1992,1997$ d) for an overview and a counter-example presented below. 
to nominal income, neglecting the possibility that money is used for non-GDP transactions.

Thus equation (1) will not be reliable when the value of non-GDP transactions, such as asset transactions, rises. In those time periods we must expect the traditional quantity equation, $\mathrm{MV}=\mathrm{PY}$, to give the appearance of a fall in the velocity $\mathrm{V}$, as money is increasingly used for transactions other than nominal GDP (PY). This explains why in many countries with asset price booms economists puzzled over an apparent 'velocity decline', 'breakdown of the money demand function' or a 'mystery of missing money'. ${ }^{18}$

The solution is to disaggregate the general equation of exchange for all transactions into two flows - those of money used for GDP ('real', hence subscript R) and those of money used for non-GDP transactions ('financial', subscript F). As Friedman pointed out about equation (3):

"Each side of this equation can be broken into subcategories: the right-hand side into different categories of transactions and the left-hand side into payments in different form" (Friedman, 'Quantity Theory', Encyclopedia Britannica, 15th edition, p. 435).

This was first successfully implemented by Werner $(1992,1997)$. Following this framework, we choose to disaggregate both sides of (1), on the one hand into money used for transactions that are part of GDP (called $M_{R} V_{R}$ ) and those that are not (called $\mathrm{M}_{\mathrm{F}} \mathrm{V}_{\mathrm{F}}$ ), and on the other hand the value of transactions that are part of GDP $\left(\mathrm{P}_{\mathrm{R}} \mathrm{Q}_{\mathrm{R}}\right)$ which should be accurately proxied by nominal GDP $\left(\mathrm{P}_{\mathrm{R}} \mathrm{Y}\right)$, and those that are not $\left(\mathrm{P}_{\mathrm{F}} \mathrm{Q}_{\mathrm{F}}\right)$ : $^{19}$

(5) $\mathrm{MV}=\mathrm{M}_{\mathrm{R}} \mathrm{V}_{\mathrm{R}}+\mathrm{M}_{\mathrm{F}} \mathrm{V}_{\mathrm{F}}$

(6) $\mathrm{PQ}=\mathrm{P}_{\mathrm{R}} \mathrm{Q}_{\mathrm{R}}+\mathrm{P}_{\mathrm{F}} \mathrm{Q}_{\mathrm{F}}$

At the same time, equations (7) and (8) must also hold:

(7) $\quad \mathrm{M}_{\mathrm{R}} \mathrm{V}_{\mathrm{R}}=\mathrm{P}_{\mathrm{R}} \mathrm{Q}_{\mathrm{R}}$

(8) $\quad \mathrm{M}_{\mathrm{F}} \mathrm{V}_{\mathrm{F}}=\mathrm{P}_{\mathrm{F}} \mathrm{Q}_{\mathrm{F}}$

Since we defined $\mathrm{P}_{\mathrm{R}} \mathrm{Q}_{\mathrm{R}}$ as the value of all transactions contributing to GDP, the value of transactions that are part of GDP should be equal to nominal GDP $\left(\mathrm{P}_{\mathrm{R}} \mathrm{Y}\right)$ :

$$
\begin{aligned}
M_{R} V_{R}= & P_{R} Y \\
& \text { with } V_{R}=\left(P_{R} Y\right) / M_{R}=\text { const. }
\end{aligned}
$$

18 Spindt (1985), Howells and Biefang-Fisancho Mariscal (1992) and Werner $(1992,1997)$.

19 As has been suggested by Werner (1992, 1994b, 1994c, 1995a, 1995b, 1995c, 1996a, 1996b, 1996c, 1996d, 1996e, 1997a, 1997b, 1997c, 1997d, 1997e, 2002b, 2003c). See also Economics Focus, The Economist, 19 June 1993, p. 74 
With a stable 'real' velocity of money, $V_{R}$, the effective amount of money used for GDP transactions during any period of time $\left(\mathrm{M}_{R} \mathrm{~V}_{\mathrm{R}}\right)$ must be equal to nominal GDP. Meanwhile, the amount of money effectively used for non-GDP transactions will be equal to the value of these non-GDP transactions.

By definition, for economic growth to take place, the value of economic transactions during one time period must exceed that of the previous period of comparison. Considering therefore net changes in variables over the observed time period, we obtain:

$$
\begin{aligned}
\Delta\left(\mathrm{M}_{\mathrm{R}} \mathrm{V}_{\mathrm{R}}\right) & =\Delta\left(\mathrm{P}_{\mathrm{R}} \mathrm{Y}\right) \\
\Delta\left(\mathrm{M}_{\mathrm{F}} \mathrm{V}_{\mathrm{F}}\right) & =\Delta\left(\mathrm{P}_{\mathrm{F}} \mathrm{Q}_{\mathrm{F}}\right)
\end{aligned}
$$

We can say that the rise (fall) in the amount of money used for GDP-based transactions is equal to the rise (fall) in nominal GDP. Similarly equation (10) states that the rise (fall) in the amount of money used for non-GDP transactions is equal to the change in the value of non-GDP transactions. In other words, an asset bubble can be caused if more money is created and injected into asset markets.

\subsection{How to Measure Money Used for Transactions}

In order to put data into these equations we must now agree on how to measure money (or, to be precise, MV, the net amount of nominal money effectively used for all transactions). As we saw, the inability to define money has been a major anomaly. Fisher, Keynes and most post-war researchers used deposit aggregates ranging from M0 to M4 to represent M in the quantity equation. But there are a number of problems with this approach.

Firstly, the original equation of exchange defines $M$ as the purchasing power that is actually exerted when transactions take place. The so-called 'money supply' ' $\mathrm{M}$ 'aggregates, as traditionally defined, mainly consist of money deposited with banks or the central bank. They measure subsets of private-sector savings and hence money that, at the moment of measurement, is not used for transactions. The original equation of exchange however demands a measure of that money which is used for transactions - money in circulation, not money out of circulation.

John Stuart Mill (1848) was clear on this point, but subsequent authors have tended to neglect it. First he defines the quantity equation as a transactions equation, as described later by Fisher and by us above. ${ }^{20}$ He then points out that

20 "The whole of the goods sold (counting each resale of the same goods as so much added to the goods) have been exchanged for the whole of the money, multiplied by the number of purchases made on the average by each piece. Consequently, the amount of goods and of transactions being the same, the value of money is inversely as its quantity multiplied by what is called the rapidity of circulation. And the quantity of money in circulation is equal to the money value of all the goods sold, divided by the number which expresses the rapidity of circulation" (Book III, Chapter 8, paragraph 13). 
"Whatever may be the quantity of money in the country, only that part of it will affect prices which goes into the market of commodities, and is there actually exchanged against goods. Whatever increases the amount of this portion of the money in the country, tends to raise prices. But money hoarded does not act on prices. Money kept in reserve by individuals to meet contingencies which do not occur, does not act on prices. The money in the coffers of the Bank, or retained as a reserve by private bankers, does not act on prices until drawn out, nor even then unless drawn out to be expended in commodities" (Book III, Chapter 8, par. 17, p. 20).

Secondly, defining money by certain private sector assets, such as deposits, creates the identification problem recognized by Friedman (1956) that "there is no hard-andfast line between 'money' and other assets" (p. 65).

Thirdly, using the traditional definition of money as cash or deposits, it remains impossible to implement a disaggregation of the money by the use it is put to. As Friedman (1956) noted, "dollars of money are not distinguished according as they are said to be held for one or the other purpose" (p. 61).

The correct definition of money for purposes of these equations is one that measures the money that actually circulates in the economy and is used for transactions at any moment in time, as Mill would have argued. It is an empirical question to find out what data conveys this information.

The issue can be reformulated: equation (9) defines nominal GDP growth $\left(\mathrm{P}_{\mathrm{R}} \mathrm{Y}\right)$. Growth this year means that more transactions (that are part of GDP) have taken place this year than last year. We know that this is only possible if more money has also exchanged hands to pay for these transactions. The next question therefore is: how can the amount of money used for transactions increase in our modern financial system? If we had a pure gold standard - which is what most classical and many neoclassical theories were designed for - then the answer would be that either gold retired from circulation (savings) is spent and put into circulation, or more gold is discovered, extracted and injected into the economy. However, today no country is on a gold standard. Instead, we have a system of fiat money. There are many different ways of organising such a system and history is full of interesting case studies.

At this juncture it is necessary to remind ourselves of the most successful (since efficient) research methodology, namely the one applied in the natural sciences: the inductive (or empirical) method. The deductive approach postulates to start with axioms and assumptions, on which theories are built which are then inevitably challenged by empirical reality. The alternative is to start with empirical facts, which are used to identify patterns and formulate theories, which then can be tested against the facts again.

How is money created and injected in our present-day system? This is a simple question that empirical research should quickly be able to answer. Intriguingly, virtually no research is published on this question at all in the leading journals of macroeconomics, monetary economics, or banking and finance. To be sure, they carry many articles that make assumptions about how a theoretical monetary system may be 
defined in the particular cases of their stylised models. This does not help us further though, if we are interested in reality.

The particular type of fiat money system that is currently employed world-wide is one in which about $97 \%$ of the money supply is created and allocated by private profit-oriented enterprises, namely the banks. How do banks create money? As Werner (1992, 1997, 2005) argued and as we show in Ryan-Collins et al. (2011), banks simply invent $97 \%$ of the money supply when they credit borrowers' bank accounts with sums of money that nobody transferred into these accounts from other parts of the economy. To use another phrase: banks create money out of nothing when they extend bank credit (or purchase other assets, or pay their staff). This is why the process of granting bank loans is better described by the expression credit creation.

It is a simple point. So much so that J. K. Galbraith (1975) said of it:

"The process by which banks create money is so simple that the mind is repelled. When something so important is involved, a deeper mystery seems only decent" (p. 18f).

On the one hand the fact that banks create the money supply is well known to a small group of experts. This is attested by many central bank publications, although mostly in obscure locations that have not attracted attention. ${ }^{21}$ It has also been recognized by Pollexfen (1697), Law (1720), Thornton (1802), John Stuart Mill (1848), Macleod (1855/56) and others (even though usually not formulated explicitly or precisely). But it failed to become the mainstream view, probably due to the fixation on legal tender or metallic money, and the subsequent focus on ' $M$ '-type deposit aggregates. Schumpeter (1954) points out that these authors recognized that in their economic effect money (traditionally measured) and bank credit could be identical:

"As soon as we realize that there is no essential difference between those forms of "paper credit' that are used for paying and lending, and that demand, supported by 'credit', acts upon prices in essentially the same manner as does demand supported by legal tender, we are on the way toward a serviceable theory of the credit structure...".

\footnotetext{
${ }^{21}$ By far the largest role in creating broad money is played by the banking sector ... When banks make loans they create additional deposits for those that have borrowed." (Bank of England, 2007). "Moneycreating organisations issue liabilities that are treated as media of exchange by others. The rest of the economy can be referred to as money holders (Bank of England, 2007). “... changes in the money stock primarily reflect developments in bank lending as new deposits are created" (Bank of England, 2007). "Given the near identity of deposits and bank lending, Money and Credit are often used almost inseparably, even interchangeably ..." (Bank of England, 2008). "Each and every time a bank makes a loan, new bank credit is created - new deposits - brand new money" (Graham Towers, 1939, former Governor of the Central Bank of Canada). "Over time ... Banknotes and commercial bank money became fully interchangeable payment media that customers could use according to their needs" (European Central Bank, 2000). "The actual process of money creation takes place primarily in banks" (Federal Reserve Bank of Chicago, 1961). "In the Eurosystem, money is primarily created through the extension of bank credit .... The commercial banks can create money themselves, the so-called giro money" (Bundesbank, 2009).

22 Schumpeter (1954), p. $718 f$.
} 
The recognition that credit may have the same economic effect as money was a major breakthrough, because legally money and credit are quite different constructs. As Schumpeter pointed out:

"And this is why Thornton's perception of the fact that the different means of payments may, on a certain level of abstraction, be treated as essentially alike was a major analytic performance, for the mere practitioner will in general be impressed by the technical differences rather than by the fundamental sameness."

The link between credit and the macroeconomy was recognized widely enough at the beginning of the twentieth century to warrant the following entry in the Enzyclopedia Britannica (1911 edition):

"The immense growth of credit and its embodiment in instruments that can be used as substitutes for money has led to the promulgation of a view respecting the value of money which may be called the Credit Theory. According to the upholders of this doctrine, the actual amount of metallic money has but a trifling effect on the range of prices, and therefore on the value of money. What is really important is the volume of credit instruments in circulation. It is on their amount that price movements depend. Gold has become only the small change of the wholesale markets, and its quantity is comparatively unimportant as determinant of prices" (italics added).

An explicit link between bank credit creation and macroeconomic activity was also made by Hahn (1920). But despite these early insights and occasional bursts of research focusing on credit, its role has remained too small in mainstream theories, especially in the post-war era. According to Schumpeter,

"it proved extraordinarily difficult for economists to recognize that bank loans and bank investments do create deposits. In fact, throughout the period under survey they refused with practical unanimity to do so" (p. 1114).

Thus this fact has not been properly reflected in macroeconomic or monetary models, and neither has it found its way into the quantity equation. ${ }^{25}$ Today, despite its simplicity, it is not generally well known, even among experts in economics and finance (as a questionnaire survey I conducted with students in Frankfurt in 2010 demonstrated). This testifies to the possibility of regressive development of knowledge in economics and finance.

However, the fact that banks create the money supply can be utilized to answer our research question at hand: In an economy with a banking system, the amount of money actually used for transactions can only increase when banks create new credit (Werner, 1992, 1997). This means that bank credit creation should have a direct impact on transaction volumes, demand, and hence also prices, as Mill (1848) and Bentham (1952-4) suggested. ${ }^{26}$

23 Schumpeter (1954), p. 719, emphasis as in original.

24 Encyclopedia Britannica (1910-1911).

25 until Werner $(1992,1997)$ that is.

${ }^{26}$ In Mill's words, not dissimilar to the at the time unpublished Bentham: "This extension of credit by entries in a banker's books, has all that superior efficiency in acting on prices, 
In order to avoid confusion we should reflect these facts in our notation by replacing letter ' $\mathrm{M}$ ' with ' $\mathrm{C}$ ', for credit. Hence our equations become:

$$
\begin{aligned}
& \text { (11) } \mathrm{CV}=\mathrm{PQ} \\
& \text { (12) } \mathrm{CV}=\mathrm{C}_{\mathrm{R}} \mathrm{V}_{\mathrm{R}}+\mathrm{C}_{\mathrm{F}} \mathrm{V}_{\mathrm{F}} \\
& \text { (13) } \mathrm{PQ}=\mathrm{P}_{\mathrm{R}} \mathrm{Q}_{\mathrm{R}}+\mathrm{P}_{\mathrm{F}} \mathrm{Q}_{\mathrm{F}} \\
& \text { (14) } \mathrm{C}_{\mathrm{R}} \mathrm{V}_{\mathrm{R}}=\mathrm{P}_{\mathrm{R}} \mathrm{Q}_{\mathrm{R}}
\end{aligned}
$$

Since we defined $P_{R} Q_{R}$ as the value of all GDP-based transactions, we also know that the following equation holds, where $\mathrm{P}_{\mathrm{R}}$ stands for the GDP deflator and $\left(\mathrm{P}_{\mathrm{R}} \mathrm{Y}\right)$ stands for nominal GDP.

$$
\begin{aligned}
C_{R} V_{R} & =\quad P_{R} Y \\
& \text { with } V_{R}=\quad\left(P_{R} Y\right) / C_{R} \quad=\text { const. }
\end{aligned}
$$

$$
\begin{aligned}
& \mathrm{C}_{\mathrm{F}} \mathrm{V}_{\mathrm{F}}=\mathrm{P}_{\mathrm{F}} \mathrm{Q}_{\mathrm{F}} \\
& \text { with } \mathrm{V}_{\mathrm{F}}=\quad\left(\mathrm{P}_{\mathrm{F}} \mathrm{Q}_{\mathrm{F}}\right) / \mathrm{C}_{\mathrm{F}} \quad \text { = const. }
\end{aligned}
$$

For growth:

$$
\begin{aligned}
& \text { (17) } \Delta\left(\mathrm{C}_{\mathrm{R}} \mathrm{V}_{\mathrm{R}}\right)=\Delta\left(\mathrm{P}_{\mathrm{R}} \mathrm{Y}\right) \\
& \text { (18) } \Delta\left(\mathrm{C}_{\mathrm{F}} \mathrm{V}_{\mathrm{F}}\right)=\Delta\left(\mathrm{P}_{\mathrm{F}} \mathrm{Q}_{\mathrm{F}}\right)
\end{aligned}
$$

\subsection{Solving Key Puzzles}

\section{Defining money}

Our simple model of disaggregated credit offers solutions to the puzzles and 'anomalies' that we have identified. Firstly, we find that the problems of the traditional approach in measuring the money supply can be addressed by employing the more accurate definition of money as credit created by the banking system (including the central bank).

which we ascribed to an extension by means of bank notes..." p. 70. "Credit which is used to purchase commodities, affects prices in the same manner as money" (p. 71).

27 Proponents of the deposit view sometimes argue that it should not matter whether deposits or loans are being analysed, as both tend to be equal in the long run. Werner (1996c) shows that in the Japanese case, a broad credit measure and M2+CD, the traditional deposit measure, diverged greatly in the 1990s. 
(1) Credit creation measures only purchasing power that is actually used for transactions at the time of measurement - which is what the equation of exchange requires, and deposit aggregates cannot deliver. Credit always represents effective purchasing power, as borrowers take out loans to engage in transactions.

(2) There is no doubt about where credit creation starts or stops - thus accurate and clear-cut measures of the effective 'money supply', namely credit creation, can be found. To be clear, only the net creation of new transferable purchasing power is part of the definition. Thus what is often termed 'credit', for instance, the issuance of corporate debt or government bonds, does not in itself constitute credit creation, as in these cases already existing purchasing power is transferred between parties. Trade credit, if not underwritten by financial institutions, is not transferrable (although it may still have economic effects, which require further research).

(3) Importantly for our disaggregated quantity equation, credit creation can be disaggregated, as we can obtain and analyse information about who obtains loans and what use they are put to. Sectoral loan data provide us with information about the direction of purchasing power - something deposit aggregates cannot tell us. By institutional analysis and the use of such disaggregated credit data it can be determined, at least approximately, what share of purchasing power is primarily spent on 'real' transactions that are part of GDP and which part is primarily used for financial transactions. Further, transactions contributing to GDP can be divided into 'productive' ones that have a lower risk, as they generate income streams to service them (they can thus be referred to as sustainable or productive), and those that do not increase productivity or the stock of goods and services. Data availability is dependant on central bank publication of such data. The identification of transactions that are part of GDP and those that are not is more straight-forward, simply following the NIA rules.

\section{Explaining the velocity decline}

The disaggregated model shows that the apparent velocity decline was due to the neglect of non-GDP transactions (financial transactions). A correct quantity equation, which is disaggregated at least into the two streams of GDP and non-GDP based transactions, should not suffer from a velocity decline. Empirical evidence for this has been offered in Werner $(1997,2005) .^{28}$

\section{Explaining what makes banks special}

\footnotetext{
While significant growth of M2+CD seemed to suggest an economic recovery in 1995, the credit aggregate suggested a contraction of nominal GDP growth - for the first time since 1931. The latter is what happened. Conversely, while M2+CD growth remained stable from mid-1995, the credit aggregate suggested a sudden economic recovery from the fourth quarter of 1995, which again materialised.

28 The very concept of velocity is also called into question by an empirical approach recognizing the reality of transaction settlement via the banking system. The original concept of velocity was based on the assumption of a gold standard and the idea that the number of times a quantity of gold circulates would increase the value of transactions that it can be used for. The mechanics are different in a modern, bank-based financial system where all non-cash transactions (close to $97 \%$ of all transaction values) are settled via the banking system. More on this elsewhere.
} 
The approach places credit creation at its centre. The ability and license to create credit is the function of banks that sets them apart from other non-bank players in the economy. That banks ration and allocate credit is recognized in the literature. But this takes on a whole new dimension of importance when it is combined with the recognition that banks are the creators of the money supply. This is the missing link that causes credit rationing (Jaffee and Modigliani, 1969, Jaffee and Russell, 1976; Stiglitz and Weiss, 1981) to have macroeconomic implications (Werner, 1992, 1997). Since the credit market is rationed and determines the money supply, the quantity and the quality of credit creation are key factors shaping the economy. This explains why non-bank sources of funding can never compensate in aggregate for a lack of bank credit: neither non-bank financial institutions, nor debt and equity markets can create credit. There are many policy implications of this fact, some of which will be explored in the second part of this paper.

\section{Explaining the ineffectiveness of interest rate reductions}

The puzzle of why over a decade of interest rate reductions failed to stimulate the Japanese economy is solved by equation (15). Nominal GDP growth is determined by credit creation used for GDP-based transactions. Interest rates do not appear in equation (15). Further, an inspection of the link between credit growth and interest rates shows that there is not a robust negative correlation between the two (Werner, 2005). In other words, it is not surprising that lower interest rates are not able to stimulate the economy, if the key variable driving growth - credit for GDPtransactions - is not growing. Likewise, raising interest rates should not slow the economy as long as credit creation for GDP transactions continues to grow.

\section{Explaining why we experience recurring banking crises}

Many empirical papers have found that banking crises follow a build-up of asset prices (e.g. Englund, 1999; Allen, 2001; Borio and Lowe, 2002; Reinhart and Rogoff, 2009). There has however not been a convincing reflection of this relationship in macroeconomic models (partly because banks do not usually feature). Equation (16) fills the gap and offers the simplest possible argument: asset inflation is caused by the creation of credit (and hence new money) by banks for asset transactions. This boosts asset prices, but their continued rise is predicated on continued credit creation for asset transactions. As soon as this is not forthcoming sufficiently, asset prices must be expected to fall, which will render speculators out of pocket and asset loans nonperforming. Due to the modest capital cushion in banking, a mere $10 \%$ drop in the present value of the loan portfolio (e.g. due to non-performance) would tend to wipe out the majority of equity, rendering the banking system subject to either runs or avoidance in the inter-bank market - both of which leave banks unable to operate.

The fact that asset prices are in aggregate determined by bank credit creation yields another important insight: the extension of credit for non-GDP transactions, if large and sustained enough, will produce a Ponzi scheme, whereby early entrants (those buying the assets that are driven up by bank credit creation) have a chance to exit with profits, while the late entrants (usually the broader public, buying at close to the peak of an asset bubble, as the media comes to focus on the phenomenal profits made by earlier entrants) will lose. The reason why credit for non-GDP transactions must be a Ponzi scheme is that only GDP transactions - as national income accountants know - 
generate the value that can yield income streams to service and repay loans. Financial transactions rely on capital gains. Thus any gains made from selling assets that have risen constitute a zero-sum game, whereby they are merely transfers from the losers. Credit creation for non-GDP transactions is thus an inherently unsustainable zero-sum game, and if large enough results in major bankruptcies, banking crises and massive resource misallocation - just like any Ponzi scheme that is large enough.

Given these dangers of credit for financial circulation, it is reasonable to contemplate how asset inflation and banking crises can be avoided - or consumer price inflation for that matter. It is commonly held among economists and the public that the process of money creation should be performed in a prudent manner. Since most commentators assume that this task is performed only by the central bank, bank credit growth and the decisions of banks as to who obtains the newly created money have often escaped attention. Once we recognize that banks are the creators of the bulk of the money supply (which many economists and finance academics may not yet do, although a growing number does), it stands to reason that some kind of responsibility goes with this privilege. Hence banks should monitor - ideally following specific rules - the quantity and quality of their credit creation.

According to equation (16), asset inflation and boom/bust cycles - and hence systemic banking crises - can be avoided if banks do not extend credit for asset transactions. It also follows fairly quickly from equation (15) that credit of the type that increases productivity or the amount of goods and services available in the economy is less likely to produce consumer price inflation than credit creation in the form of consumer loans. We can thus usefully distinguish between productive, speculative and consumptive credit creation and its monitoring can serve to predict and prevent undesirable outcomes caused by credit creation. For details, see Werner (2005).

\section{Explaining the ineffectiveness of supply-side reforms}

In Japan more than two decades of significant structural reform, deregulation, liberalization and privatization, have failed to stimulate the economy. Likewise, the structural reforms implemented in transition economies, or Greece under its debt restructuring, have not stimulated demand. This may surprise proponents of supplyside models (such as real business cycle or DSGE models). But it is easily explained in our framework, which includes a monetary sector that affects the real economy. According to equation (15), nominal GDP growth is restricted by credit creation for GDP transactions. Structural reforms may raise the potential growth rate, but if a lack of credit creation does not allow the demand side to expand, the economy will continue to grow below its potential. In this situation, the more the potential growth rate is raised through supply-side reforms, the greater the deflationary pressure would be. This seems to describe the situation in Japan well, as it is entering into the third decade of recession and deflationary pressures. It also throws a critical light on the recent argument by the World Bank (2012) that China requires structural reform to stimulate the economy and maintain high growth.

Explaining the success of the German and East Asian economic model 
Economies that manage to focus credit creation on productive and sustainable use - i.e. not for consumption and asset transactions - are likely to achieve superior economic performance (high nominal GDP growth and comparatively low inflation, without asset price cycles and with financial system stability). As the World Bank (1993) indicated, and others have also found (Patrick, 1962; Wade, 1990; Werner, 2000a, b; Werner, 2003), at the heart of the East Asian economic miracle has been a process of guiding credit towards productive use and suppressing unproductive and unsustainable (hence systemically risky) use of credit.

In East Asia this was done through the monetary policy tool of 'window guidance' (see Werner, 1998, 2002, 2003, 2005). In the wake of the banking crisis, many governments have indeed reconsidered and embraced the idea that they need to intervene in banks' credit allocation decisions (and the concept of direction of credit is now also discussed in the UK, for instance, by Lord Turner, 2011, in this issue).

However, this tool was not employed in post-war Germany. Yet the economy avoided boom-bust cycles and asset bubbles and achieved relatively high, noninflationary growth. This raises the possibility that there is an alternative to the introduction of a system of 'credit guidance' by the central bank. It stands to reason that a similar result to direct intervention can be achieved by designing the structure of the banking sector such that a type of banks is dominant that generally takes little interest in lending for financial transactions. In Germany, banking is dominated by locally-headquartered, small banks that focus on lending to the household and productive SME sector (as opposed to financial speculators). There is much discussion about the lack of funding for SMEs in the UK. This should not surprise with a highly concentrated banking system where five banks account for over $90 \%$ of deposits. In Germany, about $70 \%$ of deposits are accounted for by over 1,000 locallyheadquartered, small savings and cooperative banks (Sparkassen and Volksbanken).

\subsection{Some Empirical Evidence}

The framework can account for the anomalies identified. In addition, there is a growing body of empirical evidence in its support. Examples will be reviewed briefly.

Credit and growth

Werner (1992, 1997, 2005, 2011b), using Japanese data, shows that credit for GDP transactions explains nominal GDP well over several decades, while alternative explanatory variables (including interest rates and money supply) are eliminated in a reduction from a general to the parsimonious specific model.

Figure 1 and Table 1 show the parsimonious empirical model of Japanese nominal GDP growth cited in Werner $(1997,2005)$ :

$$
\text { (19) } \Delta \mathrm{GDP}_{\mathrm{t}}=\underset{(2.54)}{0.509}+\underset{(3.99)}{0.411 \Delta \mathrm{GDP}_{\mathrm{t}-1}}+\underset{(3.45)}{0.283 \Delta \mathrm{C}_{\mathrm{Rt}}}+\underset{0.178 \Delta \mathrm{C}_{\mathrm{Rt}-3}}{0}+\varepsilon_{\mathrm{t}}
$$


Table 1. Parsimonious Model of Nominal GDP growth

Modelling D4LnGDP by OLS; estimation sample 1984 (1) to 2001 (1)

Coeff. Std.Err. t-value t-prob Part. ${ }^{\wedge} 2$

$\begin{array}{llllll}\text { D4LnGDP_1 } & 0.411 & 0.103 & 3.99 & 0.000 & 0.197 \\ \text { Constant } & 0.509 & 0.200 & 2.54 & 0.013 & 0.090 \\ \text { D4LCR } & 0.283 & 0.082 & 3.45 & 0.001 & 0.155 \\ \text { D4LCR_3 } & 0.178 & 0.098 & 1.83 & 0.072 & 0.049\end{array}$

\begin{tabular}{|c|c|c|}
\hline Sigma & 1.043 & RSS \\
\hline $\mathrm{R}^{\wedge} 2$ & 0.887 & $\mathrm{~F}(3,65)=$ \\
\hline log-likelihood & -98.724 & DW \\
\hline no. of obs. & 69 & no. of param. \\
\hline mean(D4LnGDI & 3.410 & $\operatorname{var}(\mathrm{D} 4 \mathrm{LnGD}$ \\
\hline AR 1-5 test: & $\mathrm{F}(5,60)=$ & $1.274[0.287]$ \\
\hline ARCH 1-4 test: & $\mathrm{F}(4,57)$ & $0.666[0.618]$ \\
\hline Normality test: & $\mathrm{Chi}^{\wedge} 2(2)=$ & $4.029[0.133]$ \\
\hline hetero test: & $\mathrm{F}(6,58)=$ & $1.082[0.384]$ \\
\hline hetero-X test: & $\mathrm{F}(9,55)$ & $0.933[0.504]$ \\
\hline RESET test: & $F(1,64)$ & $0.020[0.888]$ \\
\hline
\end{tabular}

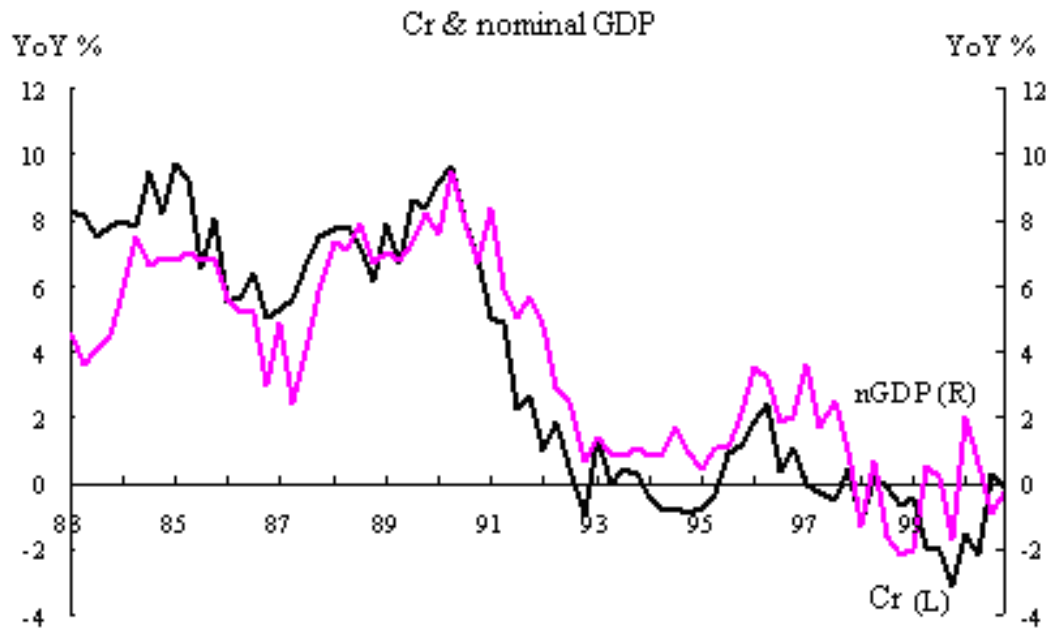

Intex: 042000 
Figure 1. Credit creation used for GDP transactions $\left(C_{R}\right)$ and nominal GDP growth in Japan. Source: Cabinet Office, Government of Japan, and Bank of Japan

King and Levine (1993) found in a 77 country study covering 3 decades that the importance of banks relative to the central bank, the percentage of credit allocated to private firms, and the ratio of credit issued to private firms to GDP are strongly and robustly correlated with growth, the rate of physical capital accumulation, and improvements in the efficiency of capital allocation.

Calza (2006) found that there is a long-run relationship linking real loans to real GDP. While the authors argue that this should be interpreted as a long-run credit demand function, they concede that the inverse relationship, with credit supply driving GDP, cannot be excluded. The latter is postulated by equation (15).

IMF (2008) found a statistically significant impact of credit growth on GDP growth in US data.

Swiston (2008) using US data found that net tightening in commercial and industrial loan standards of 20 percentage points reduces GDP by $3 / 4$ percent over 1 year and $1 \frac{1}{4}$ percent over 2 years. Further, credit availability accounts for over 20 percent of the typical contribution of financial factors to growth.

Cappiello (2010) found in a multi-country panel study on the euro area that changes in the supply of credit, both in terms of volumes and in terms of credit standards applied on loans to enterprises, have significant effects on real economic activity.

Lyonnet and Werner (this issue) found that UK credit for GDP transactions explains nominal GDP over several decades, beating monetary aggregates in a reduction from the general to the parsimonious form.

\section{Credit and asset prices}

Werner (1997, 2005) shows that credit for real estate transactions explains commercial real estate prices well.

Liang and Cao (2007) report that there exists unidirectional causality running from bank lending to property prices in China.

Davis and Zhu (2011) on Hong Kong, and Goodhart and Hofmann (2003) on a panel of countries, find significant relationships between bank credit and property prices.

These findings are in line with equation (16).

\section{Credit and banking crises}

Werner $(1992,1997,2005)$ also emphasises that increased credit growth for nonGDP (financial) transactions creates unsustainable asset price rises, followed by banking crises. Werner points out that the ratio of financial credit to total credit is a predictor of banking crises. As a more readily available approximation of whether too much credit for financial transactions is being created, total credit growth can be compared with nominal GDP growth (Werner, 1995c). By virtue of equations (15) and (16), faster total credit growth over time than nominal GDP growth can only come about by an increase in credit for financial circulation, and hence indicates a 
build-up of unsustainable financial circulation credit. This method has recently also been adopted by the Economist (2011) for the same purpose. ${ }^{29}$

Likewise, Jorda et al. (2011) applied this rule and found a close relationship between credit growth relative to GDP in the expansion phase and the severity of the following recession for 14 advanced countries over almost 140 years.

Schularick and Taylor (2012), based on the same dataset, support the view that financial crises are "credit booms gone wrong", whereby they also argue credit is the driving force and predictor of crises.

Borio and Lowe (2002) found that financial instability increases when rapid credit growth and asset price rises are observed. This is in line with equation (16), as rapid credit growth in excess of GDP growth must be due to financial transactions, thus pushing up asset prices, while being unsustainable.

Buyukkarabacak and Valev (2010) found that household credit expansions have been a statistically and economically significant predictor of banking crises. Enterprise credit expansions are weaker and less reliable in predicting banking crises. Enterprise credit expansion is likely to be a proxy for productive credit creation, which should not be associated with banking crises in our framework.

\section{Credit and the balance of payments}

Werner (1994) found that Japanese net long-term capital flows can be explained by credit creation for financial transactions (which is theoretically derived in Werner, 2005). This explained the otherwise puzzling movement of capital flows.

Buyukkarabacak and Krause (2009) distinguish between household and corporate sector credit and investigated the effects these two types of credit have on the trade balance. They found that the composition of credit does matter for the trade balance: lending to consumers has a negative effect on net exports, while loans to firms contribute to a rise in net exports. This is again empirical evidence in support of our disaggregated credit model: productive corporate loans should deliver noninflationary growth, and as part of that also exports. Consumer loans only result in greater domestic demand, which at any given marginal propensity to import will have a negative impact on the trade balance.

\section{Credit and monetary policy}

Werner (1995c) argued that central banks should use the quantity of credit creation in order to achieve nominal GDP growth targets, referring to this policy as 'quantitative easing'.

Werner (2002a) found that central bank use of credit controls and the direction of credit in East Asia goes back to an understanding of credit creation and the desire to allocate credit to productive uses. Furthermore, he argues that the development of bank-centered financing structures in many East Asian economies (as opposed to stock-market based structures in other countries) was the result of conscious

\footnotetext{
29 The Economist (2011) defines 'excessive credit expansion' as "the difference between the growth rate in bank credit and nominal GDP" (p. 69). "The fourth symptom of overheating, and one of the most important, is excessive credit expansion, which can lead to asset bubbles as well as inflation. The best measure of excess credit is the difference between the growth rate in bank credit and nominal GDP. It is normal for bank lending to grow a bit faster than GDP in an emerging economy as the financial sector develops, but credit is outpacing GDP by an alarming margin in Argentina, Brazil, Hong Kong and Turkey. Lending to the private sector has increased by around $20 \%$ or more than nominal GDP over the past year in both Turkey and Hong Kong. ...” p. 69
} 
institutional design based on the goal to direct credit to productive use and thus maximise stable growth.

Werner (2002b) found that Bank of Japan informal 'guidance' of credit ('window guidance') determined Japanese bank credit creation throughout the postwar era until including 1991. This shows that the experience of excessive bank credit expansion in the 1980s is not an indication of declining effectiveness of the direction of credit (but of the imposition of misguided loan growth targets encouraging speculative credit creation).

Goodhart and Hofmann (2003) found that bank lending is in general rather unresponsive to interest rate movements. They also argue that this finding suggests that the usefulness of interest rate policy as an instrument to smooth boom-bust cycles in asset and credit markets is questionable. This supports equation (15), as interest rates do not feature in it. The finding is also in line with earlier puzzles concerning the relationship between interest rates and growth (see above).

Chen and Werner (2011) found indirect evidence from monetary aggregates that Chinese 'window guidance' of credit is likely to remain the best indicator of the stance of monetary policy in China.

\section{Supply-determination of credit market}

Jiménez et al. (2010), in a large sample of loan applications in Spain, managed to settle the question whether the credit market is demand- or supply determined: the empirical evidence suggests credit rationing and a supply-determined credit market. This supports the thesis that credit is always rationed, even during periods of economic expansion, as Werner $(1997,2005)$ has argued.

Voutsinas and Werner (2011a) in a data set with 33,000 observations found that the supply of credit was an important constraint that influenced publicly-listed Japanese firms' corporate capital structure decisions.

In summary, our model of disaggregated credit seems consistent with the empirical evidence, which is meanwhile hard to reconcile with the standard approaches in finance or monetary economics. 


\section{Some Policy Implications}

\subsection{How to prevent Banking Crises}

Equations (17) and (18) indicate that banking crises can be avoided if bank credit is mainly used for transactions that are part of GDP, ideally for investment purposes ('productive credit creation'). ${ }^{30}$ More research is needed on the options available to regulators to achieve this. Werner (2005) has suggested to do this via regulation (the government or central bank imposing regulations on banks restricting credit creation for transactions that do not contribute to GDP). An alternative is via the design of the banking structure such that it is dominated by banks that tend not to engage in credit creation for non-GDP transactions - such as small, locally headquartered banks, including municipality-owned banks and credit unions, which account for about $70 \%$ of the banking market in Germany - as Werner (2011) argues.

\subsection{The Link between Fiscal and Monetary Policy}

What are the implications of the refined quantity equation, as presented above, for the role and impact of fiscal policy? Consider equation (17), rewritten with constant velocity:

$$
\Delta\left(\mathrm{P}_{\mathrm{R}} \mathrm{Y}\right)=\quad \mathrm{V}_{\mathrm{R}} \Delta \mathrm{C}_{\mathrm{R}}
$$

Any exogenous increase in a component of nominal GDP (such as nominal government expenditure g) cannot affect total nominal GDP, if credit creation for GDP transactions $\left(\Delta \mathrm{C}_{\mathrm{R}}\right)$ remains unaltered: assuming $\Delta \mathrm{C}_{\mathrm{R}}=0$, and breaking down nominal GDP $\left(\mathrm{P}_{\mathrm{R}} \mathrm{Y}\right)$ into nominal consumption $\mathrm{c}$, nominal government expenditure $\mathrm{g}$, nominal investment $\mathrm{i}$ and nominal net exports $\mathrm{nx}$, we obtain:

$$
\begin{aligned}
& \Delta \mathrm{C}_{\mathrm{R}}=0 \\
& \Delta\left(\mathrm{P}_{\mathrm{R}} \mathrm{Y}\right)=\Delta \mathrm{c}+\Delta \mathrm{i}+\Delta \mathrm{g}+\Delta \mathrm{nx} \\
& \Delta \mathrm{g}=-(\Delta \mathrm{c}+\Delta \mathrm{i}+\Delta \mathrm{nx})
\end{aligned}
$$

30 As labeled such by Werner (2005), but also earlier authors, including less well-known ones, such as Alan Greenspan (1967): "When banks loan money to finance productive and profitable endeavors, the loans are paid off rapidly and bank credit continues to be generally available." In contrast to financial credit: "The excess credit which the Fed pumped into the economy spilled over into the stock market -- triggering a fantastic speculative boom." 
Equation (22) indicates that the change in government expenditure $\Delta \mathrm{g}$ is countered by a change in private sector expenditure of equal size and opposite sign, as long as credit creation remains unaltered. In this framework, just as proposed in classical economics and by the early quantity theory literature, fiscal policy cannot affect nominal GDP growth, if it is not linked to the monetary side of the economy: an increase in credit creation is necessary (and sufficient) for nominal growth.

Notice that this conclusion is not dependent on the classical assumption of full employment. Instead of the employment constraint that was deployed by classical or monetarist economists, we observe that the economy can be held back by a lack of credit creation (see above). Fiscal policy can crowd out private demand even when there is less than full employment. Furthermore, our finding is in line with Fisher's and Friedman's argument that such crowding out does not occur via higher interest rates (which do not appear in our model). It is quantity crowding out due to a lack of money used for transactions (credit creation). Thus record fiscal stimulation in the Japan of the 1990s failed to trigger a significant or lasting recovery, while interest rates continued to decline.

Put simply, for unchanged credit creation (which determines the size of the income pie), an increase in government expenditure amounts to an increase in the government share of the same income pie - and hence implies a reduction in the private sector share. As Milton Friedman put it:

"The quantity theory implies that the effect of government deficits or surpluses depends critically on how they are financed. If a deficit is financed by borrowing from the public without an increase in the quantity of money, the direct expansionary effect of the excess of government spending over receipts will be offset to some extent, and possibly to a very great extent, by the indirect contractionary effect of the transfer of funds to the government through borrowing. ... If a deficit is financed by printing money, there will be no offset, and the enlarged stock of money will continue to exert an effect after the deficit is terminated. What matters most is the behavior of the stock of money, and government deficits are expansionary primarily if they serve as the means of increasing the stock of money; other means of increasing the stock of money will have closely similar effects. "31

\section{Empirical Evidence from Japan}

In 1992, the Japanese government embarked on a series of fiscal stimulus packages, with the goal to boost domestic demand. ${ }^{32}$ On average, government spending contributed almost half of growth during the 1990s, while it only contributed a sixth of growth in the 1980s (Werner, 2005).

In the general formulation of the model, with variable $\Delta C_{R}$ we find, substituting (21) into equation (17'):

31 Milton Friedman (1977), in his entry under Money: Quantity Theory in the Encyclopaedia Britannica, p. 476.

32 See the official statements at the announcement of stimulation packages. For instance: 'Keikyuu keizai taisaku (youshi), 16 November 1999, Economic Planning Agency (available at: www5.cao.go.jp/98/b/19981116b-taisakuyousi.html). 


$$
\Delta(\mathrm{c}+\mathrm{i}+\mathrm{nx}) \quad=\mathrm{V} \Delta \mathrm{C}_{\mathrm{R}}-\Delta \mathrm{g}
$$

whereby the coefficient for $\Delta \mathrm{g}$ is expected to be close to -1 . In other words, given the amount of credit creation produced by the banking system and the central bank, an autonomous increase in government expenditure $g$ must result in an equal reduction in private demand. If the government issues bonds to fund fiscal expenditure, private sector investors (such as life insurance companies) that purchase the bonds must withdraw purchasing power elsewhere from the economy. The same applies (more visibly) to tax-financed government spending. With unchanged credit creation, every yen in additional government spending reduces private sector activity by one yen.

Substituting the empirical formulation of nominal GDP, as shown in equation (19) into equation (21) and solving for non-government demand, we obtain:

$$
\Delta\left(\mathrm{c}_{\mathrm{t}}+\mathrm{i}_{\mathrm{t}}+\mathrm{nx}_{\mathrm{t}}\right)=\alpha+\beta_{1} \Delta \mathrm{GDP}_{\mathrm{t}-1}+\gamma_{0} \Delta \mathrm{C}_{\mathrm{Rt}}+\gamma_{3} \Delta \mathrm{C}_{\mathrm{Rt}-3}+\beta_{2} \Delta \mathrm{g}_{\mathrm{t}}+\varepsilon_{\mathrm{t}}
$$

The proposition of complete fiscal policy ineffectiveness can now be tested. In this case the regression would yield the following coefficient for government expenditure:

$$
\beta_{2}=-1
$$

For accurate tests, seasonally differenced absolute changes of the variables must be used. Figure 2 shows the changes in government spending and private demand during the 1990s. Table 2 shows the regression results.

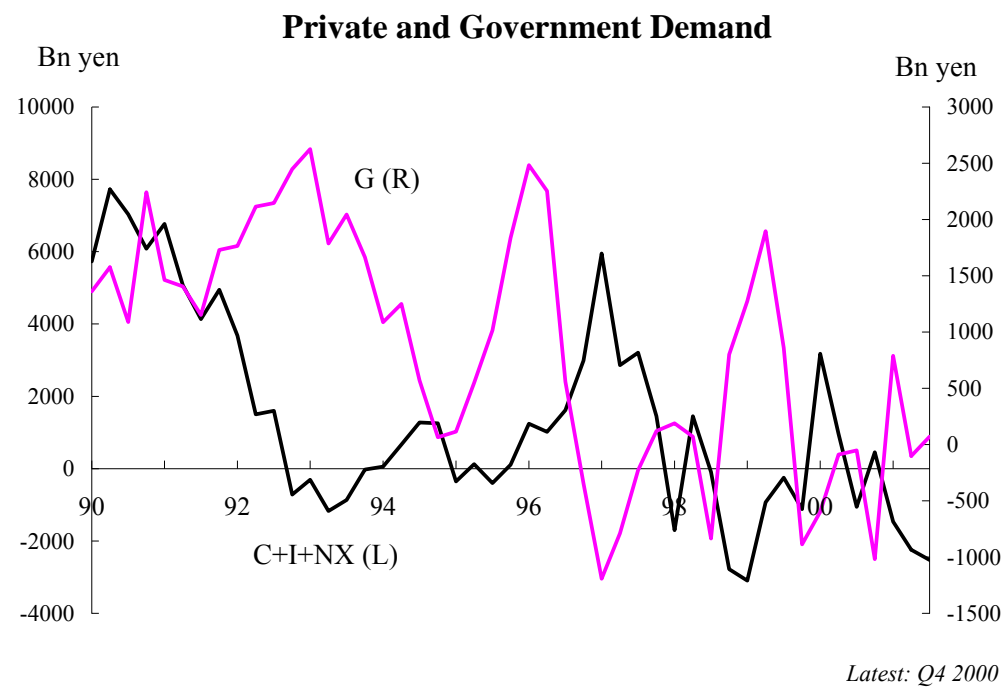

Figure 2. Nominal private demand and government expenditure, absolute growth Source: Cabinet Office, Government of Japan 
Table 2. Estimation Results of Private Demand Model

Modelling nGDP by OLS; sample 1983 (1) to 2001 (1)

$\begin{array}{llllll} & \text { Coeff } & \text { Std.Err } & \text { t-val } & \text { t-prob } & \text { Part.R^2 } \\ \text { Constant } & 440.29 & 244.6 & 1.80 & 0.076 & 0.046 \\ \text { D4nGDP_1 } & 0.476 & 0.098 & 4.85 & 0.000 & 0.257 \\ \text { D4CR } & 0.085 & 0.031 & 2.75 & 0.008 & 0.100 \\ \text { D4CR_3 } & 0.059 & 0.036 & 1.64 & 0.105 & 0.038 \\ \text { D4G } & -0.974 & 0.140 & -6.94 & 0.000 & 0.415\end{array}$

$\begin{array}{llll}\text { Sigma } & 1231.87 & \mathrm{RSS} & 103190221 \\ \mathrm{R}^{\wedge} 2 & 0.832 & \mathrm{~F}(4,68)= & 83.97 \quad[0.000]^{* *} \\ \text { log-likelihood } & -620.482 & \mathrm{DW} & 2.03 \\ \text { no. of obs. } & 73 & \text { no. of param. } & 5 \\ \text { mean(D4CINX) } & 2441.51 & \text { var(D4CINX) } & 8.39605 \mathrm{e}+006\end{array}$

$\begin{array}{llll}\text { AR 1-5 test: } & \mathrm{F}(5,63)= & 1.214 & {[0.313]} \\ \text { ARCH 1-4 test: } & \mathrm{F}(4,60)= & 0.605 & {[0.661]} \\ \text { Normality test: } & \mathrm{Chi}^{\wedge} 2(2)= & 5.672 & {[0.059]} \\ \text { hetero test: } & \mathrm{F}(8,59)= & 1.990 & {[0.064]} \\ \text { hetero-X test: } & \mathrm{F}(14,53)= & 1.772 & {[0.068]} \\ \text { RESET test: } & \mathrm{F}(1,67)= & 0.199 & {[0.657]}\end{array}$

The coefficient for government expenditure $\left(\beta_{2}\right)$ is -0.974 . Rounding to one decimal digit, we obtain:

$$
\beta_{2}=-1.0 .
$$

The empirical evidence is consistent with the contention that an economic recovery requires monetary expansion, here defined as credit creation.

The finding suggests that Japanese fiscal policy has been ineffective during the 1990s (but also the prior and subsequent decades, as tests show), because it was not supported by monetary policy. Ironically, this ineffectiveness finding may provide a strong case for using fiscal expenditure policy as an effective avenue for stimulating the economy, especially in times when bank credit is stagnating - fiscal policy, that is, which is appropriately coordinated with suitable monetary policy. The need for coordination of fiscal and monetary policy has been emphasised previously by economists such as Lerner (1943), Wray (2001), but also Schabert (2004). ${ }^{33}$

33 Wray (2001) frames his argument in terms of high-powered money, which however does not necessarily translate to greater effective spending: “... when demand is low, the private 
Policy-makers that wish to stimulate growth can do so by increasing credit creation. There are a number of options available. One is via fiscal policy that is funded by credit creation or other measures that increase credit creation (as Werner, 1995 c, suggested in Japan, referring to this as 'quantitative easing' - an expression which was later borrowed by central banks to refer mainly to conventional monetarist bank reserve or high powered money expansion - for which many expressions already existed). As Blinder and Solow (1973:323) pointed out, there "is no controversy over government spending financed by printing money. ... it will be expansionary".

The central bank could act to increase credit creation, and hence stimulate the economy, by raising its net open market purchase operations. Policies to stimulate bank credit creation could also have been adopted. Here, the central bank could utilize its unique status to solve the bad debt problem (by purchasing bad debts at face value, as suggested in Werner, 1996b). Given these findings, it appears central bank policy has not been as helpful as it could have been. The lack of incentives to coordinate monetary policy with the government's fiscal policy may be one of the disadvantages of central bank independence. ${ }^{34}$

\section{A More Effective Way to Monetise Fiscal Policy}

There is a policy for governments to monetise fiscal policy even without cooperation from the central bank. The method, first suggested by Werner (1996c, 1998a, 2000c) renders fiscal policy effective, according to the above model. The Ministry of Finance could cover the public sector borrowing requirement by substituting bond finance with borrowing from the private sector commercial banks. This would increase credit creation and stimulate the economy.

Thus funding of fiscal expenditure by borrowing from banks would increase credit creation and hence the total amount of purchasing power in the economy. As a result, $\Delta \mathrm{C}_{\mathrm{R}}$ in equation (17') above would rise, which would, in turn, boost nominal GDP. By shifting government funding away from bond finance and replacing it with borrowing from the commercial banks via simple loan contracts, credit creation will be stimulated. ${ }^{35}$ Unlike bond markets, banks create new purchasing power when they

sector will not create money endogenously, hence, the government must expand the supply of HPM through fiscal policy."

34 Independence is not necessarily an obstacle, since a central bank can voluntarily cooperate to support the government's policy. As Bernanke (2000) pointed out, "Cooperation with the fiscal authorities in pursuit of a common goal is not the same as subservience" (p. 163). Unfortunately, there are few examples of such cooperation by independent central banks.

35 This is effectively the policy combination adopted by the Reichsbank from 1933 to 1937. Its President, Hjalmar Schacht, appeared to have been well aware of the quantity crowding out problem of unmonetised fiscal policy. In addition to stepping up the credit creation of the Reichsbank (by purchasing various forms of assets, including government bonds and bonds of other government institutions), Schacht instructed the establishment of government institutions that implemented fiscal spending programmes and were funded by the issuance of bills of exchange that were purchased by the banks and the central bank. Funding fiscal expenditure with money creation, as opposed to public bond auctions is called 'silent funding' (geraeuschlose Finanzierung) in the German tradition. 
lend. This means that overall economic activity can be boosted (via fiscal policy), without any quantity crowding out that rendered fiscal policy ineffective during the 1990 s. ${ }^{36}$

Figures 3 and 4 are used to illustrate the difference between stimulatory fiscal policy - here the example of a fiscal spending package - funded via bond issuance taken up by investors, such as life insurers, and stimulatory fiscal policy that is backed by credit creation.

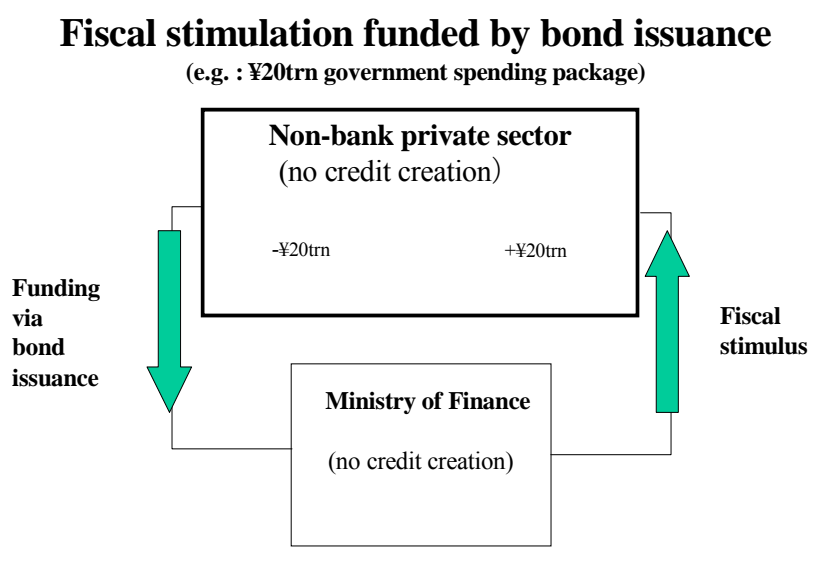

Net Effect $=$ Zero

Figure 3.

36 The Werner (1996c, 1998a, 2000c) proposal is supported and seconded by economists such as Congdon (2001), Smithers (2001) and the Financial Times' Martin Wolf (2002), although they fail to cite it. 


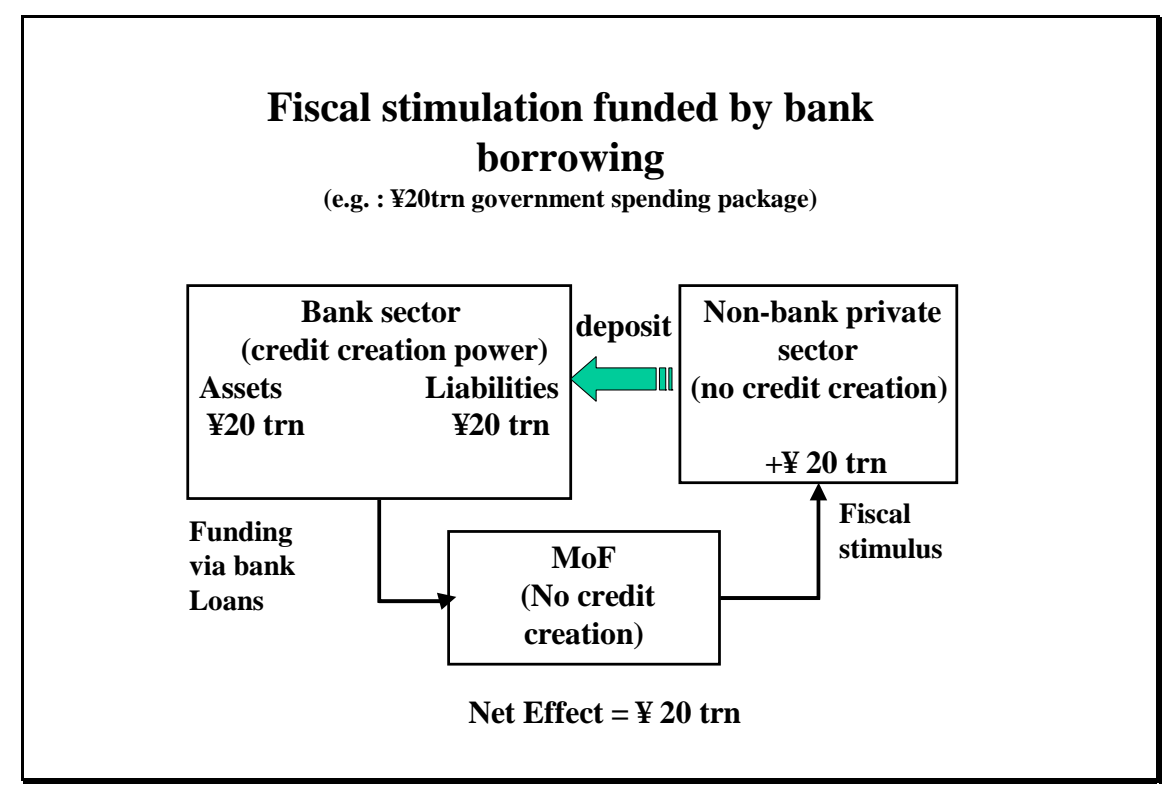

Figure 4. Bond-funded fiscal policy vs. bank-funded fiscal policy

Although the central government funded parts of the 1998 budget from banks, this has remained negligible in size. With the majority of bond issuance taken up by the non-bank private sector (which does not have the power to create credit), fiscal spending had to crowd out private activity.

Germany in 1968, under finance minister Karl Schiller, funded about $70 \%$ of the public sector borrowing requirement (amounting to DM13bn) through long-term borrowing from private banks. More recently, such as in 1999, Germany funded its public sector borrowing requirement (amounting to E35bn, approx. DM70bn), entirely through the issuance of government bonds, and, additionally, reduced its borrowing from financial institutions (by a net E10bn, approx. DM20bn) ${ }^{37}$ The model seems consistent with such evidence and the observation that fiscal policy in the late 1960s seemed more effective and fiscal multipliers were larger, than in the late 1990s or presently. It provides an explanation for this puzzle of declining fiscal multipliers.

\subsection{A proposal to solve the European sovereign debt crisis}

37 I am grateful to Mr Wolfgang Eichmann, Head of Section III of the German Federal Statistical Office, for kindly writing to me, upon reading some of my work, and pointing out these supportive facts from Germany to me. See also Eichmann's (2002) relevant article on the velocity of money, which, among others, cites Werner (1997). 
A main drawback of the recent policies to tackle the European sovereign debt crisis has been that none addresses the central problem of falling growth in the periphery. What is required is a policy that not only shields the borrowing of the Eurozone governments from adverse market movements (such as rising yields due to speculative attacks or downgrades by rating agencies), but more importantly one that stimulates economic growth in the eurozone.

Politicians and market participants have proposed that the ECB should purchase (more) European government bonds. This may be based on the understanding that the central bank is the principal creator of the money supply. However, central banks only create about $3 \%$ of the money supply in most economies. The vast majority is created and allocated by private-sector profit-oriented enterprises, the commercial banks. It is thus more logical to ask the banks to help fund government expenditure. Applying the Werner (1996c, 1998a, 2000c) proposal to the eurozone, we find that governments can stabilise their borrowing costs and stimulate domestic demand by a desecuritisation of their funding operations: instead of issuing government bonds, a superior policy would be to borrow the public sector borrowing requirement from the commercial banks in their respective country (Siekmann and Werner, 2011). For instance, they can enter into 3-year loan contracts at the prime rate (which as of November 2011 was lower than the longer dated bond yields for all affected periphery countries). The prime rate is closer to the banks' refinancing costs of $1 \%$.

The immediate savings would be substantial, as this method of enhanced debt management reduces the new borrowing costs. Instead of governments injecting money into banks, banks would give money to governments. This helps the banking sector, as its core business, to extend credit, is expanded, thus increasing retained earnings. These can then be used by banks to shore up their capital. There are substantial savings to the taxpayer as new bank rescues become largely unnecessary. Bank credit to the government will not be forced (as is forbidden in the EU treaties) but on a voluntary basis, at the prime rate. Eurozone governments remain zero risk borrowers according to the Basel capital adequacy framework (banks are thus happy to lend).

Finally, this proposal addresses the core underlying problem: slowing growth and the need to stimulate it. From the credit model we know that the proposal will boost nominal GDP growth - and avoid crowding out from the bond markets. This is especially a problem as fiscal policy has tightened in the eurozone, and monetary policy is de facto also tight: bank credit is slowing down sharply, and recently has turned to contraction in many eurozone countries, including Germany and the periphery. Bank credit extension is credit creation, adding to the money supply. From the credit model we know that the proposal will boost nominal GDP growth - and avoid crowding out from the bond markets. This increases employment and tax revenues. It can push countries back from the brink of a deflationary and contractionary downward spiral into an upward cycle of growth, greater tax revenues and falling debt/GDP.

Would banks be willing to lend to governments? 
Banks have become risk-averse and are only willing to lend to the lowest risk borrowers. This is the government, able to command in theory even lower rates than the private sector prime rate. The Basel capital adequacy framework reflects this reality. This is also true for periphery countries: banks' solvency is ultimately guaranteed by governments, not the other way round. Thus lending to their governments, when undertaken as part of this proposal, will not hurt the banks. To the contrary, it will improve banks's P\&L and balance sheets, as well as the fiscal situation of the governments concerned, directly and indirectly, as economic growth will be boosted.

The European Central Bank's Long-Term Refinance Operation (LTRO), announced on 8 December 2011, offered banks unlimited funding at a fixed interest rate of $1 \%$, while formalizing that all bank lending is eligible as collateral for central bank funding. By February 2012, over 1 trn Euro in LTRO funding were borrowed by banks. However, much of this money is put into deposit with the ECB system. This policy on its own is thus not likely to be sufficient to accelerate bank credit creation. One problem is that banks are required to mark to market any securities holdings, thus limiting the appeal of investing in periphery government bonds. What is needed is an increase in the supply of bank credit through loan contracts, which do not have to be marked to market.

After the ECB has replaced the market-based funding of banks via the interbank market with its direct lending programme, governments need to match this policy by replacing the market-based government funding via the bond market with a direct government borrowing programme via loan contracts from the commercial banks. This policy would boost domestic demand in the countries that adopt it, as bank credit creation would accelerate, in line with equation (17).

Ideally, such a policy is part and parcel of a new approach to monetary and fiscal policy which I believe would end the so-called European crisis quickly and at minimal cost, without threatening either exit or further centralization of decisionmaking powers. The key policies I would suggest the ECB to adopt are:

1. The ECB should purchase all non-performing assets from all Eurozone banks at face value, in exchange for banks agreeing to comply with a new 'credit guidance regime' run by the ECB.

2. The ECB should introduce and operate this new 'credit guidance', whereby the $\mathrm{ECB}$ via its NCBs requires banks to meet monthly and quarterly quotas concerning the growth of total credit outstanding AND the credit outstanding in each of the subcategories of credit, on which banks have to report on a monthly basis as well, namely:

A. bank credit for GDP transactions, divided into mortgage credit for newbuilds to households, consumer credit, credit to the manufacturing industry (divided into further specific industries, though no sub-targets set), credit to the construction sector, credit to the non-financial service sector (divided further into specific industries), R\&D, education, other categories 
B. bank credit for non-GDP transactions, divided into credit to other banks, credit to non-bank financial institutions, credit to financial or property holding companies, mortgages or loans to purchase existing assets, other categories

whereby the ECB via its NCBs restricts credit to type B sectors and sets positive YoY\% growth targets for credit of type A.

3. The ECB should institute a loan guarantee scheme for the most desirable types of loans loans, i.e. to the manufacturing sector implementing new technology, environmentally enhancing and sustainable energy producing sector, as well as in $\mathrm{R} \& \mathrm{D}$ and education. Loans are guaranteed by the ECB.

4. The ECB should immediately re-introduce the Bundesbank's bill rediscounting operations, expanded to all NCBs and extended to firms in type A sectors, but Eurozone-wide, via the NCBs.

5. Until above scheme has got traction, the ECB, via its NCBs introduces a new direct lending facility whereby the NCBs extend credit to type A sector borrowers.

6. The ECB should introduce a new scheme, whereby the ECB and NCBs meet with the national finance/treasury ministries and debt management offices in order to end the issuance of government bonds in the markets and instead fund all public sector borrowing requirements (that must meet unchanged Brussels budgetary requirements) through direct loan contracts from the national banks. This reduces borrowing costs sharply, as the prime rate is lower, helps banks as their business expands without further capital adequacy requirements (risk weights are zero), while the loans do not need to be marked to market, but can be used for ECB refinancing. (The Werner-Siekmann proposal).

7. The ECB should meet with national bank regulators, the European Banking Authority and the BCBS in order to negotiate release of eurozone banks from the Basel capital adequacy standards for the coming three years, until bank credit growth and hence nominal GDP growth is back to full employment levels. 


\section{Bibliography}

Allen, F. (2001). Financial Structure and Financial Crisis. International Review of Finance, 2:1/2, 2001: pp. 1-19.

Allen, Roy E. (1989), Globalization of the U. S. Financial Markets: The New Structure for Monetary Policy, in Richard O'Brian and Tapan Datta (eds.), International Economics and Financial Markets, Oxford: Oxford University Press, pp. 266-286.

Asako, Kazumi (1991), The land price bubble in Japan, Ricerche Economiche, vol. 45, no. 2-3, pp. 451-468.

Ashcraft, A. B. (2005). 'Are Banks Really Special? New Evidence from the FDICinduced Failure of Healthy Banks', American Economic Review, Vol. 95, No. 5, Bank Crisis on Real Activity in the United States', American Economic Review,

Belongia, M. T. and Chalfant, J. A. (1990). Alternative Measures of Money as

Bentham, Jeremy (1952-54), Bentham's Economic Writings, Critical Edition Based On His Printed Works and Unprinted Manuscripts, three volumes edited by Werner Stark and the Royal Economic Society, Allen \& Unwin

Bernanke, Ben S. (1993a), Credit in the macroeconomy, Federal Reserve Bank of New York Quarterly Review, vol. 18, no. 1, Spring, pp. 50-70.

Bernanke, Ben S. (1993b), How important is the credit channel in the transmission of monetary policy? A comment, Carnegie-Rochester Conference Series on Public Policy, vol. 39, December, pp. 47-52.

Bernanke, Ben S. (2000), Japanese monetary policy: A case of self-induced paralysis?, in: Ryoichi Mikitani and Adam S. Posen (2000), Japan's Financial Crisis and its Parallels to US Experience, Special Report 13, September, Washington D.C.: Institute for International Economics

Bernanke, Ben S. and Mark Gertler (1995), Inside the black box: The credit channel of monetary policy transmission, Journal of Economic Perspectives, vol. 9, no. 4, Fall, pp. 27-48.

Black, J. and Randow, J. (2011). Trichet turns 'President of Europe' as crisis stuns politicians. Bloomberg News, August 09.

Blanchard, O. J. and Fischer, S. (1989). Lectures on Macroeconomics, Cambridge,

Blinder, A. S. and Solow, R. M. (1973), Does fiscal policy matter?, Journal of Public Economics, vol. 2, pp. 319-337. 
Bloomberg Editorial (2011). Available at: < http://www.bloomberg.com/view/2011$\underline{10-25 />}$ October 25

Borio, C., and Lowe, P. (2002). Asset Prices, Financial and Monetary Stability: Exploring the Nexus. BIS Working Papers, No. 114.

Boughton, J. M. (1991). Long-run money demand in large industrial countries, IMF Staff Papers, vol. 38, no. 1, March, pp. 1-32

Buyukkarabacak, B. and Stefan Krause (2009), Studying the effects of household and firm credit on the trade balance: The composition of funds matters, Economic Inquiry, Vol. 47, No. 4, October, 653-666

Buyukkarabacak, B. and Valev, N., (2010). The role of household and business credit in banking crises. Journal of Banking and Finance. 34, pp. 1247-1256

Calza, A. et al., (2006). Credit in the euro area: an empirical investigation using aggregate data. The Quarterly Review of Economics and Finance. 46, pp. 211-226

Cappiello, L. et al., (2010). Do bank loans and credit standards have an effect on output?A panel approach for the Euro area. European Central Bank, Working Paper No 1150 , January 2010

Caprio, J. and Klingebiel, D. (1999) Episodes of systemic and borderline financial crises, mimeo, Washington, DC: World Bank, October.

Congdon, T. (2001), Money and the Japanese Economic Crisis, Lombard Street Research Monthly Economic Review, August

Congress (2010). 'The Financial Crisis and the Role of the Federal Regulators,' Hearing before the Committee on Oversight and Government Reform, House of Representatives, 110th Congress, second session, on 23 October 2008. Washington: Government Printing Office, accessed at https://house.resource.org/110/ gov.house.ogr.20081023_hrs15REF2154.raw.txt

Cramer, J. S. (1986), The volume of transactions and the circulation of money in the United States, 1959-70, Journal of Business and Economic Statistics, April 1986, vol. 4, no. 2, pp. 232-252.

Davis, E. and Zhu, H., (2011). Bank lending and commercial property cycles: some cross- country evidence. Journal of International Money and Finance. 30, pp. 1-21

Dokko, Yoon, Robert H. Edelstein and E. Scott Urdang (1990), Does credit rationing affect residential investment? Deja vu all over again, Journal of Real Estate Finance and Economics, vol. 3, no. 4, pp. 357-371

Dore, Ronald (1986), Flexible Rigidities: Industrial Policy and Structural Adjustment in the Japanese Economy 1970-80, Stanford: Stanford University Press

Dotsey, M., Lantz, C., and Scholl, B. (2003) The Behaviour of the Real Rate of Interest, Journal of Money, Credit and Banking, Vol. 35, No. 1. 
Easterly, W., and Fisher, S. (1990) The Economics of the Government Budget Constraint, The World Bank Research Observer, Vol. 5, No. 2, pp. 127-42.

Economist (2011), Some like it hot, Which emerging markets are at the greatest risk of overheating? , Economics Focus, 2 July 2011, p. 69 (UK edition)

Eichmann, Wolfgang (2002), Sinkt die Geldumlaufgeschwindigkeit?, Wirtschaftsdienst, vol. 82, no. 2, February

Englund, P. (1999). The Swedish Banking Crisis: Roots and Consequences. Oxford Review of Economic Policy, Vol. 15, No. 3.

Fama, E. F. (1985). 'What's Different about Banks', Journal of Monetary Economics,

Fisher, Irving (1911), The Purchasing Power of Money, Its Determination and Relation to Credit, Interest and Crises, New York: Macmillan.

Fisher, Irving (1926), The Purchasing Power of Money, Its Determination and Relation to Credit, Interest and Crises, 2nd ed., assisted by Harry G. Brown, New York: Macmillan.

French, Kenneth R. and James M. Poterba (1991), Were Japanese stock prices too high?, Journal of Financial Economics, vol. 29, pp. 337-363.

Friedman, M. (1956), The quantity theory of money - A restatement, in: Milton Friedman (ed.), Studies in the Quantity Theory of Money, Chicago: University of Chicago Press

Friedman, M. (1992). The Mystery of Money, in Money Mischief: Episodes in Monetary History. A Harvest Book, Harcourt Brace \& Company.

Friedman, M. (1977), 'Quantity Theory', Encyclopaedia Britannica, XVth edition. Galbraith, J. W. (1996). Credit rationing and threshold effects in the relation between money and output, Journal of Applied Econometrics, vol. 11, pp. 419-429

Gelb, A. H. (1989) Financial policies, growth, and efficiency, Policy Research Working Paper Series, No. 202, World Bank.

Goldfeld, S. M. (1976), The case of the missing money, Brookings Papers on Economic Activity, no. 3, pp. 683-730.

Goodhart, C. A. E. (1989). 'The Conduct of Monetary Policy', Economic Journal, Goodhart, C. and Hofmann, B., (2003). Deflation, credit and asset prices. HKIMR Working Paper No.13/2003

Gordon, R. J. (1984). The 1981-82 Velocity Decline: A Structural Shift in Income or Money Demand? NBER Working Paper, No. 1343. 
gov.house.ogr.20081023_hrs15REF2154.raw.txt

Government Printing Office, accessed at https://house.resource.org/110/

Gürkaynak, R. S., Sack, B., and Swanson, E. (2005) The Sensitivity of Long-Term Interest Rates to Economic News: Evidence and Implications for Macroeconomic Models, The American Economic Review, Vol. 95, No. 1.

Greenspan, Alan (1967), Gold and Economic Freedom, in Ayn Rand, Nathaniel Branden, Alan Greenspan, Robert Hessen (eds.), Capitalism, the Unknown Ideal, Signet

Hahn, A. (1920), Volkswirtschaftliche Theorie des Bankkredits, Tuebingen, J.C.B. Mohr.

Handa, J. (2000). Monetary Economics, London and New York: Routledge.

Hayashi, Fumio (1998), Keizai Kyōshitsu - Nichigin, besu mane no mokuhyō wo (The BoJ should set a base money target), Nihon Keizai Shinbun, December 29 (in Japanese)

Hendry, D. F. (1985). Monetary Economic Myth and Econometric Reality, Oxford Review of Economic Policy, Vol. 1, No. 1, 72-84.

Hendry, David F. (2000), Econometrics: Alchemy or Science? New Edition. Oxford: Oxford University Press

Hendry, David F. and Grayham E. Mizon (1978), Serial correlation as a convenient simplification, not nuisance: A comment, Economic Journal, vol. 88

Hetzel, R. L. (1984). Estimating Money Demand Functions. Journal of Money, Credit and Banking, Vol. 16, No. 2, May, 1984, Ohio State University Press.

Howells, Peter and Iris Biefang-Frisancho Mariscal (1992), An explanation for the recent behavior of income and transaction velocities in the United Kingdom, Journal of Post Keynesian Economics, vol. 14, no. 3, Spring, pp. 367-388.

http://web.mit.edu/krugman/www/japtrap2.html

IMF (2008). Global Financial Stability Report: financial stress and deleveraging. IMF Publication, April 2008

Jaffee, Dwight and Franco Modigliani (1969), A theory and test of credit rationing, American Economic Review, vol. 59, pp. 850/872

Jaffee, Dwight and Thomas Russell (1976), Imperfect information, uncertainty and credit rationing, Quarterly Journal of Economics, vol. 90, pp. 651-666. 
Jiménez, Gabriel, Steven Ongena, José-Luis Peydró and Jesús Saurina (2010), Credit Supply: Identifying Balance-Sheet Channels with Loan Applications and Granted Loans, ECB Working Paper

Johnson, Chalmers A. (1988). 'Studies of Japanese Political Economy: A crisis in theory', Japan Foundation Newsletter, 16, December, pp. 1-11

Johnson, Chalmers A. (1999). 'The Developmental State: Odyssey of a Concept', in Meredith Woo-Cumings (ed.), The Developmental State, Ithaca: Cornell University Press

Johnson, S. (2009). The Economic Crisis and the Crisis in Economics. Speech prepared for the Presidential Address to the Association for Comparative Economics, San Francisco, January 4, 2009.

Jorda, Oscar, Moritz H. P. Schularick and Alan M. Taylor (2011), When credit bites back: Leverage, business cycles and crises, NBER Working Paper No. 17621

Judd, J.P. and J.L. Scadding (1981). Liability Management, Bank Loans, And Deposit "Market" Disequilibrium. Federal Reserve Bank of San Francisco Economic Review, Summer 1981.

Judd, J.P. and J.L. Scadding (1982). The search for a stable money demand function: A survey of the post-1973 literature, Journal of Economic Literature, vol. 20, pp. 993-1023.

Keikyuu keizai taisaku (youshi), (1999), Economic Planning Agency (available at: www5.cao.go.jp/98/b/19981116b-taisakuyousi.html), November 16

Keynes, John Maynard (1930), A Treatise on Money, Vol. 1, London: Macmillan.

King, R. G., and Levine, R. (1993) Finance and Growth: Schumpeter might be right, The Quarterly Journal of Economics, Vol. 108, Issue 3, pp. 717-737.

Klein, Lawrence R. (1968), The Keynesian Revolution, London: Macmillan

Kohn, D. L. (2009). Monetary Policy Research and the Financial Crisis: Strength and Shortcomings. Speech at the Federal Reserve Conference on Key Developments in Monetary Policy, Washington, D.C., October 9, 2009.

Krugman, Paul (1998a), Japan's Trap, mimeo, May, obtained at: http://web.mit.edu/krugman/www/japtrap.html.

Krugman, Paul (1998b), Setting Sun - Japan: What went wrong?, mimeo, 11 June, obtained at: http://web.mit.edu/krugman/www/japan.html.

Krugman, Paul (1998c), It's Baaack: Japan's slump and the return of the liquidity trap, Brookings Papers on Economic Activity, no. 2, pp. 137-205. 
Krugman, Paul (1998d), Japan: Still trapped, mimeo, November, obtained at:

Kuhn, Thomas S. (1962), The Structure of Scientific Revolutions, Chicago: University of Chicago Press.

Kuttner, K. N., and Mosser, P. C. (2002) The monetary transmission mechanism in the United States: some answers and further and questions, BIS Papers, No. 12, Market functioning and central bank policy, pp. 433-443.

Lakatos, I. (1970), Falsification and the methodology of scientific research programmes, in I. Lakatos and A. Musgrave (eds.) Criticism and the Growth of Knowledge, Cambridge: Cambridge University Press.

Law, J. (1720), Money and Trade Consider'd with a Proposal for Supplying the Nation with Money, By Mr. John Law, now Director of the Royal Bank at Paris, London.

Leary, M. T. (2009). 'Bank Loan Supply, Lender Choice, and Corporate Capital

Leeper, E. M., and D. B. Gordon (1992), In search of the liquidity effect, Journal of Monetary Economics, vol. 29, pp. 341-69.

Lequiller, F. (2004) The Treatment of Provisions in the National Accounts: Elements for the Review of the SNA. Issue prepared for the December 2004 Meeting of the Advisory Expert Group on National Accounts, OECD.

Lerner, Abba P. (1943), Functional finance and the federal debt, Social Research, vol. 10, no. 1, February, MA, MIT Press.

Liang, Qi and Hua Cao (2007), Property prices and bank lending in China, Journal of Asian Economics, 18, 63-75

Macleod, H. D. (1855/56), The Theory and Practice of Banking: With the Elementary Principles of Currency, Prices, Credit and Exchanges, London, Longman, Brown, Green and Longman, Volumes 1 and 2.

Melvin, M. (1983), The vanishing liquidity effect of money on interest: Analysis and implications for policy, Economic Inquiry, April, pp. 188-202.

Mill, J.S. (1848), Principles of Political Economy: With Some of their Applications to Social Philosophy, London, Hackett Publishing

Miller, S. M. (1986). Financial innovation, depository-institution deregulation, and the demand for money, Journal of Macroeconomics, Vol. 8, Issue 3, pp. 279-296.

Miller, Roger L. and David D. VanHoose (1993), Modern Money and Banking, $3^{\text {rd }}$ ed., New York: McGraw-Hill 
Newcomb, S. (1885), Principles of Political Economy, New York: Harper

Niggle, Christopher J. (1988), The increasing importance of financial capital in the US economy, Journal of Economic Issues, vol. 22, June, pp. 581-8.

No. 2, pp. 276-309, Berlin, Duncker und Humblot.

Oakley, D. and Milne, R. (2011), Investors cautious on Greek bail- out, Financial Times, 22 July

Okina, Junio (1999), Monetary policy under zero inflation: A response to criticisms and questions regarding monetary policy, Bank of Japan Monetary and Economic Studies, vol. 17, no. 3, December, pp.172

Patrick, H. T. (1962), Monetary Policy and Central Banking in Contemporary Japan, Bombay, University of Bombay.

Peek, J. and Rosengren, E. S. (2000). 'Collateral Damage: Effects of the Japanese

Pigou, Alfred C. (1917), The value of money, Quarterly Journal of Economics, vol. 32, November, pp. 38-65.

Polak, J. J. (1989) Financial Policies and Development, OECD, Development Centre, Paris.

Polak, J. J. (1989) Strengthening the Role of the IMF in the International Monetary System, in: Gwin, Catherine and Richard E. Reinberg (eds.), 1989, pp. 45-68.

Policy, Princeton, NJ, Princeton University Press.

Popper, Karl Raimund (1968), Conjectures and Refutations, New York: Harper Collins

Pollexfen, J. (1697), A Discourse of Trade, Coyn, and Paper Credits: and of Ways and Means to Gain, and Retain Riches, London, Brabazon Aylmer. pp. 1712-1730.

Reinhart, C. and Rogoff, K. (2008) Is the 2007 U.S. Sub-Prime Financial Crisis So Different? An International Historical Comparison, NBER Working Paper, No. 13761.

Reinhart, C. and Rogoff, K. (2008) This Time is Different: A Panoramic View of Eight Centuries of Financial Crises, NBER Working Paper, No. 13882.

Reinhart, C. M. and Rogoff, K. S. (2009), The Aftermath of Financial Crises, American Economic Association, Vol 99(2), pages 466-72.

Representatives, 110th Congress, second session, on 23 October 2008. Washington: Reserve Bank of St. Louis, November/December 1990. 
Roley, V. V. (1986). Money Demand Predictability. NBER Working Paper, No. 1580.

Romer, D. (2006). Advanced Macroeconomics. $3^{\text {rd }}$ edn., McGraw-Hill Higher Education.

Roubini, N. and Sala-i-Martin, X. (1992) Financial Repression and Economic Growth, Journal of Development Economics, Vol. 39, Issue 1, pp. 5-30.

Ryan-Collins, J., Greenham, T., Werner, R. and Jackson, A., 2011, Where Does Money Come From? A Guide to the UK Monetary System, London, New Economics Foundation.

Schabert, Andreas (2004), Interactions of monetary and fiscal policy via open market operations, The Economic Journal, vol. 114, March

Schularick, Moritz and Alan M. Taylor (2012), Credit Booms Gone Bust: Monetary Policy, Leverage Cycles and Financial Crises, 1870- 2008, American Economic Review

Schumpeter, J. A. (1954), History of Economic Analysis, New York: Oxford University Press.

Selden, R. T. (1956), Monetary velocity in the United States, in: Milton Friedman (ed.), Studies in the Quantity Theory of Money, Chicago: University of Chicago Press.

Siekmann, Helmut and Richard A. Werner (2011), Eine einfache und gerechte Lösung der Schuldenkrise, Börsen-Zeitung, 09.12.2011, Nummer 238, page 7

Smaghi, B. (2011), Die Euro-Zone reformieren, Handelsblatt, July 12, p. 56

Smithers, A. (2001), The importance of funding policy for Japan's recovery, Smithers \& Co., 29 September

Spencer, Roger W. and William P. Yohe (1970), The "crowding out" of private expenditures by fiscal policy actions, Federal Reserve Bank of St. Louis Review, vol. 52, October, pp. 15

Sørensen, Peter Birch and Hans Jørgen Whitta-Jacobsen (2010), Introducing Advanced Macroeconomics, $2^{\text {nd }}$ Edition, New York: McGraw-Hill

Spindt, Paul A. (1985), Money is what money does: Monetary aggregation and the equation of exchange, Journal of Political Economy, vol. 93, pp. 175-204.

Stiglitz, Joseph and Andrew Weiss (1981), Credit rationing in markets with imperfect information, American Economic Review, vol. 71, no. 3, June, pp. 393-410. 
Stiglitz, Joseph E. (2001), Information and the change in the paradigm in economics, Prize Lecture, given on the occasion of the award of the Bank of Sweden Prize in Economic Sciences, December 8, 2001, obtained at: http://www.nobel.se/economics/laureates/2001/stiglitz-lecture.pdf.

Stiglitz, Joseph E. and Bruce Greenwald (2003), Towards a New Paradigm in Monetary Economics, Cambridge: Cambridge University Press.

Stock, J. H., and Watson, M. W. (1999) Forecasting Inflation, NBER Working Paper, No. 7023.

Stone, Courtenay C., and Daniel L. Thornton (1987), Solving the 1980s' velocity puzzle: A progress report, Federal Reserve Bank of St. Louis Review, August/September, pp. 5-23.

Swiston, A., (2008). A US Financial Conditions Index: putting credit where credit is due. IMF Working Paper WP/08/161

Taleb, N. N. (2009). Ten principles for a Black Swan-proof world. Financial Times, published: April 7, 2009.

Taylor, J. B. (1999) A Historical Analysis of Monetary Policy Rules, Monetary Policy Rules, University of Chicago Press.

Thornton, H. (1802), An Enquiry into the Nature and Effects of the Paper Credit of Great Britain, London, Hatchard.

Trichet, J-C. (2011), Building Europe, building institutions. Karlspreis 2011, Aachen, June 2

Turner, A. (2011), Speech at the European Conference on Banking and the Economy, 29 September, Winchester Guildhall, UK.

Ueda, K. (1990) Japanese Capital Flows, Journal of Banking and Finance, Vol. 14, Issue 5, pp. 1079-1101.

Voutsinas, K. and Werner, R. A. (2011a). 'Credit Supply and Corporate Capital Structure: Evidence from Japan', International Review of Financial Analysis 20, 320334

Voutsinas, K. and Werner, R. A. (2011b), 'Testing the Effectiveness of QE: Evidence from Japan', CBFSD Discussion Paper No. 2-2011, Centre for Banking, Finance and Sustainable Development, University of Southampton

Wade, R. (1990), Governing the Market: Economic Theory and the Role of Government in East-Asia Industrialization, Princeton University Press.

Walsh, C. E. (2003). Monetary Theory and Policy, $2^{\text {nd }}$ edn, Cambridge, MA, MIT 
Werner, R. A. (1992), Towards a quantity theorem of disaggregated credit and international capital flows, paper presented at the Royal Economic Society Annual Conference, York, April 1993, and at the 5th Annual PACAP Conference on PacificAsian Capital Markets in Kuala Lumpur, June 1993

Werner, Richard A. (1994a), Japanese foreign investment and the 'land bubble', Review of International Economics, vol. 2, no. 2, June, pp. 166-178

Werner, Richard A. (1994b), May edition, Liquidity Watch, Tokyo: Jardine Fleming Securities (Asia) Ltd.

Werner, Richard A. (1995a), Bank of Japan: Start the Presses!, Asian Wall Street Journal, Tuesday, 13 June

Werner, Richard A. (1995b), June edition, Liquidity Watch, Tokyo: Jardine Fleming Securities (Asia) Ltd.

Werner, Richard A. (1995c), Keizai Kyōshitsu: Keiki kaifuku, ryōteki kinyū kanwa kara, Nihon Keizai Shinbun, 2 September (English translation on eprints.soton.ac.uk)

Werner, Richard A. (1996a), Has there been a 'credit crunch' in Japan?, paper presented at the Fifth Convention of the East Asian Economic Association (EAEA), Bangkok, October

Werner, Richard A. (1996b), Nichigin Manipulation, Ronso Toyo Keizai, Part I: July, pp. 64-73; Part II: September, pp. 130-9; Part III: November, pp. 190-5, Tokyo: Toyo Keizai Shinpo Sha

Werner, R. A. (1997), Towards a new monetary paradigm: A quantity theorem of disaggregated credit, with evidence from Japan, Kredit und Kapital, vol. 30, no. 2, pp. 276-309

Werner, R. A. (1998a), Minkan ginko kara no kariire de, keikitaisaku wo okonaeba 'issekinicho', Shukan Economist, 14 July, Mainichi Shinbunsha, Tokyo

Werner, R. A. (1998b), Bank of Japan window guidance and the creation of the bubble, in: Florentino Rodao and Antonio Lopez Santos (eds.), El Japon Contemporaneo, Salamanca: University of Salamanca Press.

Werner, Richard A. (2000a), Indian macroeconomic management: At the crossroads between government and markets, in: Ghon S. Rhee (ed.), Rising to the Challenge in Asia: A Study of Financial Markets, Vol. 5, India, Manila: Asian Development Bank

Werner, Richard A. (2000b), Macroeconomic management in Thailand: The policyinduced crisis, in: Ghon S. Rhee (ed.), Rising to the Challenge in Asia: A Study of Financial Markets, Vol. 11, Thailand, Manila: Asian Development Bank 
Werner, Richard A. (2000c), Japan's plan to borrow from banks deserves praise, Financial Times, 9 February

Werner, Richard A. (2002b), The "enigma" of Japanese policy ineffectiveness in the 1990s, The Japanese Economy, vol. 30, no. 1, pp. 25-95.

Werner, R. A. (2002a), Monetary policy implementation in Japan: what they say vs. what they do, Asian Economic Journal, vol. 16, no. 2, June, pp. 111-151.

Werner, R. A. (2002b), A reconsideration of the rationale for bank-centered economic systems and the effectiveness of directed credit policies in the light of Japanese experience, Japanese Economy, vol. 30, No. 3, May/June, pp. 3-45

Werner, R. A. (2003), Princes of the Yen: Japan's Central Bankers and the Transformation of the Economy, Armonk, New York: M. E. Sharpe.

Werner, Richard A. (2003c), Fukeiki ga owaranai hontōno riyū (Central Banking and Structural Change), Tokyo: Soshisha (in Japanese).

Werner, R.A. (2004) No recovery without reform? An evaluation of the evidence in support of the structural reform argument in Japan. Asian Business and Management, 3, (1), 7-38. (doi:10.1057/palgrave.abm.9200077).

Werner, R., (2005). New Paradigm in Macroeconomics: solving the riddle of Japanese macroeconomic performance. England: Palgrave Macmillan.

Werner, R.A. (2006) The relationship between interest rates and economic activity: How the conventional literature has dealt with the Japanese experience. In, Batten, J.A., Fetherston, T.A. and Szilagyi, P.G. (eds.) Japanese Fixed Income Markets: Money, Bond and Interest Rate Derivatives. Amsterdam, Holland, Elsevier, 135-170.

Werner, R. A. (2011), An Analytical Evaluation of a Potential Obstacle to Enhanced Performance by Credit Unions, in: Graham Manville and Richard Greatbanks (eds.), Performance Measurement and Management in the Third Sector, Gower Publishing

Werner, R., Ryan-Collinas, J., Greenham, T. and Jackson, A., (2011). Where does money come from? A guide to the UK monetary and banking system. new economics foundation (nef)

Wicksell, Knut (1898), Geldzins und Gueterpreise: eine Studie ueber die den Tauschwert des Geldes bestimmenden Ursachen, Jena: Gustav Fischer

Wolf, M. (2002), How to avert a ratings disaster, Financial Times, March 27

Woo-Cumings, Meredith, ed. (1999), The Developmental State. Cornell, CA: Cornell University Press 
Woodford, M. (2003). Interest and Prices: Foundations of a Theory of Monetary

World Bank (1993), The East Asian Economic Miracle, Washington: International Bank for Reconstruction and Development

World Bank (2012), China 2030: Building a Modern, Harmonious, and Creative High-Income Society, Washington: International Bank for Reconstruction and Development

Wray, Randall (2001), The endogenous money approach, Center for Full Employment and Price Stability, Working Paper No. 17, August. 